\title{
Gestão dos Terrenos Comunitários. Análise dos Planos de Utilização dos Baldios
}

\author{
Iryna Skulska*, Maria do Loreto Monteiro** e Francisco Castro \\ Rego***
}

Sumário. Os terrenos comunitários (baldios) ocupam atualmente cerca de meio milhão de hectares em Portugal continental e constituem um património valioso e um importante espaço agroflorestal. Em 1976, os baldios foram devolvidos às comunidades rurais após décadas de ocupação pelo Estado Novo e reflorestação sob o Regime Florestal.

Em 2007, entre a Direcção-Geral dos Recursos Florestais e as principais federações florestais com intervenção nos baldios foi assinado um protocolo para a elaboração de Planos de Utilização dos Baldios (PUB), tendo vindo a ser produzidos 830 planos. Entre 2016 e 2019 toda a informação, relacionada com os PUB foi recolhida para organização de uma base de dados com 664 planos, bem como para o procedimento de análise estatística com o objetivo de comparar as quatro principais modalidades de gestão dos baldios.

Os resultados obtidos permitiram caracterizar as florestas comunitárias. A maior parte das áreas florestais baldias estavam administradas em cogestão com o Estado verificandose que, em todas as modalidades de gestão analisadas, a produção florestal prevalece como uma das principais aptidões e estratégias. A maioria destas florestas é composta por coníferas, apontando-se o interesse da conversão para florestas mistas. Os PUB permitiram também conhecer muitas outras características dos baldios e da sua gestão e forneceram indicações diversas sobre o potencial destas áreas para o desenvolvimento de novas atividades económicas.

Palavras-chaves: Floresta comunitária; modalidades de gestão; planos florestais; estratégia

*Investigadora, ***Professor c/Agregação. Centro de Ecologia Aplicada "Prof. Baeta Neves" (CEABN), InBIO, Instituto Superior de Agronomia. Universidade de Lisboa. Tapada da Ajuda, 1349017 LISBOA

E-mail: irynaskulska@isa.ulisboa.pt; frego@isa.ulisboa.pt

*Professora Coordenadora Aposentada. Escola Superior Agrária de Bragança do Instituto Politécnico de Bragança.Quinta de Sta. Apolónia, Apartado 1172, 5301-855 BRAGANÇA

E-mail: mloretomonteiro@gmail.com 
Management of Community Land. Analysis of Baldios Use Plans

Abstract. The community lands (baldios) cover about half a million hectares and are very valuable in terms of heritage and spaces for agroforestry activities. In 1976, the Estado Novo returned these lands to rural communities after decades of occupation and reforestation under the Forest Regime.

In 2007, a protocol was signed between the Directorate General of Forestry Resources and the main baldio related forest federations, and 830 plans (Planos de Utilização dos Baldios - PUB) were prepared. Between 2016 and 2019 all the information relating to 664 of these PUBs were collected for the development of a database and for statistical analysis purposes, in order to compare the four main management models.

The results allowed for the characterization of the community forests. Most of these areas were under a co-management model with the State, and we concluded that, in all the modalities under analysis, forest production prevails as one of the main potential uses and strategies. Conifers dominate these areas and the conversion to mixed forests is encouraged. The analysis of the PUBs allowed for the understanding of many other characteristics of the baldios as well as their potential for the development of new economic activities.

Key words: Community forest; management modalities; forestry plans; strategy

\section{Gestion des Terres Communautaire. Analyse des Plans d'Utilisation de Baldios}

Résumé Les terrains communautaires, désignées au Portugal par baldios, occupent environ un demi-million d'hectares et constituent un patrimoine de grand valeur et un espace agroforestier très important. En 1976, ces terres communautaires ont été restitués aux communautés rurales après de décennies d'occupation par l'Estado Novo et de reboisement, sous le Régime Forestier.

En 2007, un protocole a été signé entre la Direction Générale des Ressources Forestières et les principales Fédérations Forestières associées aux baldios pour l'élaboration de ses plans d'utilisation (PUB). De cette façon 830 plans ont été élaborées. Entre 2016 et 2019, toutes les informations sur 664 de ces PUB ont été réunies pour l'organisation d'une base des données, ainsi que pour la procédure d'analyse statistique pour comparer les quatre principaux types de gestion.

Les résultats obtenus permettent de caractériser les forêts communautaires. La plupart de ces zones forestières etaient gérées en cogestion avec l'Etat et, dans tous les modalités analysées, la production forestière est considérée comme une des principales vocations et stratégies. Les conifères sont dominants dans les forêts, mais la conversion en forêts mixtes, ainsi que le développement de nouvelles activités économiques doivent être encouragées.

Mots-clés: Forêt communautaire; modalités de gestion; plans forestiers; stratégie 


\section{Introdução}

Em 2014, ano que marcou os 40 anos sobre a revolução de 25 de Abril, as comunidades rurais celebraram também a devolução dos seus terrenos comunitários baldios. Estes terrenos constituíram um marco desde a Idade Média. Mas, em vários documentos oficiais dessa altura foram designados como "terrenos incultos", como por exemplo na Lei Sesmarias de 1375 (REGO, 2001). Outra referência importante aos baldios foi datada de 1455, num documento de D. Afonso V, onde esses terrenos são tratados como "bens comuns", possuídos e geridos por um conjunto de pessoas, residentes num determinado lugar, constituindo muito provavelmente o que hoje chamamos de "baldios" (FERREIRA e SOARES, 2013).

Durante a monarquia liberal, outro importante marco resultou da proposta apresentada pelas Cortes de 18 de abril de 1821 no sentido de se avançar com o fim dos baldios, devido a visões políticas (considerando a posse comunitária da terra como um regime ineficaz), ambientais (necessidade do controlo de erosão do solo nessas áreas e bacias hidrográficas) e económicos (uso destes terrenos para a produção florestal). No entanto, no início século $X X$ fez-se um reconhecimento geral dos baldios para a sua posterior submissão ao Regime Florestal ${ }^{1}$ que no caso dos terrenos comunitários, é considerado como Regime Florestal Parcial ${ }^{2}$. Estas áreas foram reflorestadas durante o Estado Novo, na vigência do Plano de Povoamento Florestal (PPF), que previa a arborização de 420 mil hectares (DEVY-VARETA, 2003; GERMANO, 2000; REGO e SKULSKA, 2019). O PPF foi projetado para vigorar durante 30 anos e previa o desenvolvimento de administrações florestais e infraestruturas adicionais consideráveis (caminhos, casas de guarda, postos de vigia e rede telefónica). Esta ocupação pelo Estado alterou fortemente o uso do solo nos terrenos baldios e o estilo de vida das comunidades locais, sobretudo em zonas rurais marginais.

Após a revolução de 25 de Abril os terrenos baldios foram devolvidos ao povo no âmbito do Decreto-Lei n. ${ }^{0} 39 / 76$ de 19 de janeiro, e consagrada na

\footnotetext{
${ }^{1}$ Por Regime Florestal entende-se o conjunto de disposições destinadas não só à criação, exploração e conservação da riqueza silvícola, sob o ponto de vista da economia nacional, mas também o revestimento florestal dos terrenos cuja arborização seja de utilidade pública, e conveniente ou necessária para o bom regime das águas e defesa das várzeas, para a valorização das planícies áridas e benefício do clima, ou para a fixação e conservação do solo, nas montanhas, e das areias no litoral marítimo(parte VI, artigo 25. ${ }^{\circ}$, do Decreto de 24 de dezembro de 1901).

${ }^{2} \mathrm{O}$ Regime Florestal é Parcial quando aplicado a terrenos baldios, a terrenos das autarquias ou a terrenos de particulares, subordinando a existência de floresta a determinados fins de utilidade pública, permite que na sua exploração sejam atendidos os interesses imediatos do seu possuidor (parte IV, artigos $26 . .^{\circ}$ e $27 .{ }^{\circ}$, do Decreto de 24 de dezembro de 1901).
} 
Constituição a propriedade comunitária, constituindo um marco inabalável. Porém, em períodos seguintes, surgiram, naturalmente outras leis relacionadas com os baldios com o objetivo de adaptar às condições reais da altura e, sobretudo, valorizar a gestão destes terrenos ${ }^{3}$.

A gestão florestal dos baldios submetidos ao Regime Florestal tornou-se um desafio para os seus proprietários - os compartes. Por um lado, a gestão florestal exigia um certo conhecimento, sendo difícil de realizar sem apoio técnico. A presença do Regime Florestal não permitia alterar o uso do solo o que juntamente com outros fatores contribuiu para diminuir o interesse dos compartes na gestão das suas florestas (BAPTISTA, 2010). Mas, ao mesmo tempo, a maturação dos povoamentos e o elevado nível das receitas provenientes da venda de madeira nos anos seguintes à devolução dos baldios, influenciaram positivamente o interesse na gestão dos seus recursos florestais (SKULSKA et al., 2020).

Além disso, as transformações registadas nas áreas rurais de muitos países europeus nas últimas décadas (modernização da agricultura, agravamento de problemas ambientais, declínio demográfico em zonas rurais, redução do peso da agricultura e da sua capacidade de empregabilidade) também afetaram Portugal (CANADAS e NOVAIS, 2014). Desde a década de 70 do século passado até aos dias atuais, a atitude em relação à gestão de recursos florestais sofreu uma série de mudanças significativas. O conceito de floresta como fonte de matériasprimas, empregos e renda nas áreas rurais cimentou-se a partir dos anos 80, devido ao declínio da influência da agricultura. Nas décadas seguintes surgiu uma nova visão do papel das florestas nas áreas rurais, com maior foco em novas, ou atualizadas, funções da floresta (por exemplo, conservação, biodiversidade e paisagem, suporte para atividades de lazer e recreio) (BAPTISTA, 2010; LOPES et al., 2015; RADICH e BAPTISTA, 2005). As condições da vida rural mudaram e provocaram transformações nas comunidades rurais tradicionais. De uma comunidade de utilizadores do baldio, passou-se para uma unidade que gere rendas (BAPTISTA, 2010).

A administração dos baldios também se alterou completamente. Em alguns baldios, os compartes demonstram grande interesse e intervêm na gestão dos seus terrenos, noutros a gestão foi assegurada por autarquias locais ou Serviços Florestais (SF). Apesar dos trabalhos realizados por BAPTISTA et al. (2002), GOMES (2009) e SKULSKA et al. (2020) à escala nacional e regional, as diferenças entre as diversas modalidades de gestão dos baldios têm sido pouco analisadas, pelo que

${ }^{3}$ Por exemplo a Lei dos Baldios n. ${ }^{\circ}$ 68/93, de 4 de setembro; Lei n. ${ }^{\circ}$ 89/97 de 30 de julho, DecretoLei n. ${ }^{\circ}$ 165/2015, de 17 de agosto e atual em vigor Lei n. ${ }^{\circ}$ 75/2017 de 17 de agosto. 
constitui o objetivo global deste estudo.

\section{Floresta comunitária}

Depois da reflorestação imposta e promovida pelo Estado Novo, a ocupação florestal passou a ter um grande relevo nos baldios. Todos os estudos realizados até à data sublinham a importância dos povoamentos florestais na paisagem e na economia dos baldios, embora a sua grandeza e área de ocupação atual permaneçam muito pouco conhecidas.

Se bem que muitas fontes indiquem que os baldios ocupam cerca de $500 \mathrm{mil}$ hectares, a área exata destes permanece desconhecida. $\mathrm{O}$ "Reconhecimento dos baldios do continente", executado pela JCI em 1939 identificou 7638 baldios com a área total de 407544 hectare, dos quais 332370 hectares com aproveitamento florestal. Mas os autores da obra acautelaram que: "...não se tratou de um trabalho cadastral, $\log o$ as indicações sobre a área [...] não devem considerar-se como absolutamente rigorosos".

O estudo de BAPTISTA et al. (2002) que recaiu sobre 820 baldios do Norte de Portugal, mostrou que a floresta se encontra presente na esmagadora maioria das unidades $(88 \%)$. Uma outra análise realizada no âmbito do Programa Nacional para a Valorização dos Territórios Comunitários indicou que a área baldia florestal submetida ao Regime Florestal em 2010 era de 412143 hectares (AFN, 2010).

Planos de Utilização dos Baldios e dos seus recursos florestais

A publicação do Decreto-Lei n. ${ }^{\circ}$ 39/76 de 19 de janeiro, consagrou a figura dos Planos de Utilização dos Recursos Baldios (PUB), cometendo a sua elaboração à Administração Pública, mas durante três décadas estes nunca foram concretizados. Os PUB foram definidos de novo na Lei n. ${ }^{\circ}$ 68/93, de 4 de setembro. O Decreto-Lei n. ${ }^{\circ}$ 205/99 de 9 de junho reforçou a obrigatoriedade de submeter as Matas Nacionais e Comunitárias a Planos de Gestão Florestal. Nos anos seguintes a importância de melhorar os modelos de governança das áreas florestais baldias e respetiva sustentabilidade económica, bem como a necessidade de desenvolver os planos de gestão, foi indicada tanto no Plano Nacional de Defesa da Floresta contra Incêndios como na Estratégia Nacional para as Florestas (PCM, 2006). Além de isso, esta Estratégia reconheceu a 
necessidade de recuperação do potencial que representa a gestão do espaço baldio, melhorando e vitalizando a cogestão entre o Estado e as Comunidades.

Um momento de grande importância neste processo ocorreu em 2006, após a

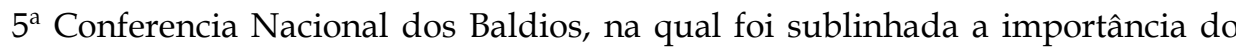
desenvolvimento de planos de gestão florestal nas florestas comunitárias, bem como a integração das florestas comunitárias nos Planos Regionais de Ordenamento Florestal. Na reunião entre a Secretaria de Estado do Desenvolvimento Rural e Florestas, a DGRF (Direção Geral dos Recursos Florestais, designação dos Serviços Florestais do Estado à data) e a BALADI (Federação Nacional dos Baldios), pretendendo dar seguimento às conclusões da conferência acordaram um protocolo plurianual entre a DGRF e a BALADI para a elaboração dos Planos de Utilização de Baldios envolvendo todos os baldios em cogestão com o Estado ou em regime de transição. Protocolos semelhantes foram acordados com outras duas estruturas associativas florestais, a Associação Florestal de Portugal - FORESTIS e a Federação dos Produtores Florestais de Portugal (FPFP).

No dia 16 de fevereiro de 2007, entre a DGRF e as referidas entidades foram celebrados protocolos com vista à elaboração dos PUB até ao fim de 2008, para um máximo de 650 mil hectares de área baldia e no montante total máximo de 1,3 milhões de euros ( $2 € /$ hectare), através do apoio financeiro do Fundo Florestal Permanente (FFP) de acordo com o Quadro 1. As áreas máximas e correspondentes financiamentos para cada entidade foram definidas, por excesso, por haver indefinição sobre qual a estrutura escolhida pelos compartes para elaboração dos PUB e pelo deficiente conhecimento das áreas de cada unidade de baldio.

Quadro 1 - Distribuição do financiamento e da área baldia para a elaboração dos PUB em protocolos celebrados entre a Direção Geral dos Recursos Florestais e Federações Florestais com intervenção na gestão de baldios

\begin{tabular}{|c|c|c|c|}
\hline $\begin{array}{c}\text { Data de Assinatura } \\
\text { do Protocolo }\end{array}$ & $\begin{array}{c}\text { Entidades / } \\
\text { Federações }\end{array}$ & $\begin{array}{c}\text { Financiamento Máximo } \\
\text { (mil euros) }^{*}\end{array}$ & $\begin{array}{c}\text { Área Máxima Abrangida } \\
\text { (mil hectares) }\end{array}$ \\
\hline \multirow{3}{*}{16.02 .2008} & BALADI & 700 & 350 \\
\cline { 2 - 4 } & FORESTIS & 400 & 200 \\
\cline { 2 - 4 } & FPFP & 200 & 100 \\
\hline \multicolumn{2}{|r|}{ Total } & $\mathbf{1 3 0 0}$ & $\mathbf{6 5 0}$ \\
\hline
\end{tabular}

* Valor máximo, acrescendo a estes montantes o imposto sobre o valor acrescentado (IVA) à taxa legal em vigor $(21 \%)$

É importante mencionar que, durante esse processo, a FPFP foi desativada por 
insolvência, tendo as suas responsabilidades pela elaboração dos planos sido repartidas entre as federações BALADI e FORESTIS.

A estrutura dos PUB deveria respeitar as regras descritas no Decreto-Lei 205/99 e conter as seguintes componentes: enquadramento da unidade baldia; diagnóstico do seu funcionamento; análise simplificada de usos e ocupações do solo; opções de utilização futura, e o plano de intervenções prioritárias. Todos os PUB deveriam incluir a cartografia digital do baldio. Os ficheiros criados em formato Shapefile ou numa geodatabase deveriam ser uniformizados no que respeita ao sistema de coordenadas, formatos e modos de apresentação. Em colaboração com a Universidade de Trás-os-Montes e Alto Douro (UTAD), foi desenvolvida uma estrutura que facilitava a criação das bases de dados dos PUB por via Microsoft Access.

No início de 2016, recolheu-se no âmbito deste estudo toda a informação possível sobre o processo de submissão, análise e homologação dos PUB, nas instalações do Instituto para a Conservação da Natureza e Florestas (ICNF) situadas em Vila Real, Viseu, Lousã e Lisboa, e na sede da BALADI.

Para a realização deste estudo foi conseguida a recolha de 776 PUB, com uma área total de 316813 hectares. Destes, em 2018, apenas 664 (86\%) estavam aprovados e homologados, cobrindo uma área de 285236 hectare (90\% do total). Com base nos documentos recolhidos neste estudo pretendeu-se atinguir os seguintes objetivos: (i) analisar a história do processo da elaboração e aprovação dos PUB; (ii) criar uma Base de Dados com toda a informação extraída dos PUB aprovados e homologados pelo ICNF; (iii) comparar o atual estado da gestão dos recursos comunitários e as atividades desenvolvidas nas principais modalidades de gestão; (iv) propor soluções de melhoria com base nos resultados obtidos.

\section{Metodologia}

Recolha da informação de base

O processo de submissão e aprovação dos PUB tornou-se bastante mais complexo do que o inicialmente planeado. Apesar de a cessação do protocolo ter sido prevista para o dia 31 de dezembro de 2008, o período de elaboração e entrega dos PUB foi estendido e mais de uma centena encontram-se ainda em 2020 não homologados.

Segundo a informação recolhida no âmbito deste estudo, o atraso foi provocado por vários motivos: a falência de uma das federações responsáveis 
pela elaboração dos PUB, a FPFP (Federação dos Produtores Florestais de Portugal); interrupções na colaboração entre os principais atores do protocolo; as várias atualizações da estrutura do Access, criada para a submissão dos PUB; as frequentes reformas estruturais nos serviços florestais, nomeadamente a transformação da DGRF em AFN (Autoridade Florestal Nacional) em 2008 e, de seguida, em ICNF em 2012, e as distintas abordagens aplicadas na avaliação dos PUB pelos serviços regionais dos serviços florestais no Norte e no Centro de Portugal. Como resultado, dos 224 planos submetidos no Centro de Portugal apenas 149 (66,5\%) foram aprovados. Durante o estudo não se conseguiu identificar o destino dos restantes 75 planos em falta.

Ao longo de todo este processo foram elaborados 830 PUB, $90 \%$ pelas duas principais federações: BALADI e FORESTIS.

Para a criação da Base de Dados (BD), e a partir do acesso à informação pelo ICNF, foram utilizados todos os ficheiros Access disponibilizados, cópias de todos os 664 PUB homologados e mapas com limites de baldios georreferenciados.

O processo de construção da BD iniciou-se com a exportação do Access para o Excel de toda informação recolhida, e sua posterior organização num único documento. De seguida, toda a informação do documento foi verificada e complementada para cada baldio, com base nas cópias dos correspondentes PUB homologados.

Surgiram certas dificuldades relacionadas com a falta de informações sobre os PUB homologados no Centro de Portugal. Embora o acesso geral aos processos dos PUB na Direção Regional do ICNF em Viseu tenha sido bastante satisfatória, a informação relativa a $27 \%$ dos PUB aprovados estava incompleta. Em muitos documentos, recolhidos em formato digital e impresso, faltaram várias componentes importantes, como por exemplo o plano de gestão, o mapa e/ou ofício da homologação do PUB.

Organização da base de dados e agrupamento das variáveis

Na fase preparatória para a análise estatística, todas as variáveis do PUB na base de dados foram agrupadas da seguinte forma: 1 . Administração; 2. Recursos florestais; 3. Outros recursos naturais em gestão e atividades desenvolvidas; 4. Infraestruturas; 5 . Aptidões e estratégias na gestão dos recursos baldios.

Muitas dessas variáveis incluem descrições qualitativas e quantitativas detalhadas. A localização geográfica indica a localização de cada Unidade Baldia, 
incluindo uma descrição dos terrenos vizinhos, área de ocupação e situação com litígios no seu limite. O grupo de variáveis relativo à administração inclui uma descrição da entidade responsável pela gestão dos baldios, o tipo de gestão (autónoma ou cogestão com Estado) e a localização da sede, bem como outra informação. A parte relacionada com a gestão florestal inclui informação sobre a dimensão destas atividades em cada baldio, descrição da ocupação do solo e dos procedimentos de condução operacional desenvolvidos. A terceira parte da BD descreve a quantidade e/ou qualidade dos Produtos Florestais Não Lenhosos (PFNL), bem como o estado da sua exploração. A descrição das infraestruturas apresenta informações sobre as casas de guarda, rede viária e pontos de água. Aptidões e estratégias de gestão dos baldios constituem o último grupo desta análise.

\section{Modalidades de gestão comparadas}

Atualmente, existem várias modalidades de gestão dos baldios, resultantes da combinação de dois critérios principais: tipo de gestão (autónoma ou em cogestão com Estado) e tipo de entidade que as gere (Conselho Diretivo, Autarquias Locais ou Serviços Florestais). O histórico da sua ocorrência e complexidade será discutido mais adiante no texto, na parte dos resultados. Nesta análise foram avaliadas e comparadas entre si apenas as quatro modalidades de gestão mais representativas, apresentadas no Quadro 2.

Quadro 2 - As quatro principais modalidades de gestão das áreas baldias analisadas neste estudo

\begin{tabular}{|c|c|c|}
\cline { 2 - 3 } \multicolumn{1}{c|}{} & Gestão Autónoma (GA) & Cogestão (CG) \\
\hline Conselho Diretivo (CD) & CD-GA & CD-CG \\
\hline Junta de Freguesia (JF) & JF-GA & JF-CG \\
\hline
\end{tabular}

A análise da distribuição das modalidades em estudo à escala nacional indica que estas não têm igual representatividade, sendo os modelos em cogestão os mais frequentes, como se pode verificar na Figura 1. À escala nacional 71,6\% dos baldios são cogeridos com o Estado (Figura 1a) enquanto nos PUB analisados este valor se reduz ligeiramente para 65,5\% (Figura 1b). Também à escala nacional os baldios geridos por Conselhos Diretivos representam cerca de $60 \%$ das unidades 
enquanto que neste estudo a percentagem de PUB analisados este valor se reduz para $46 \%$.

a)

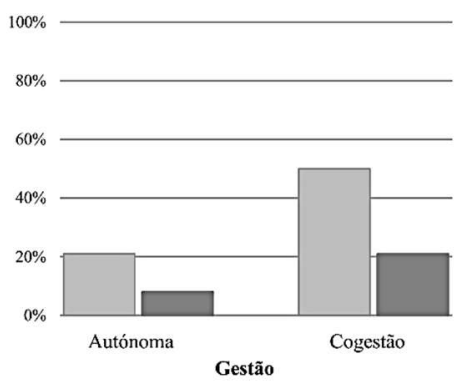

b)

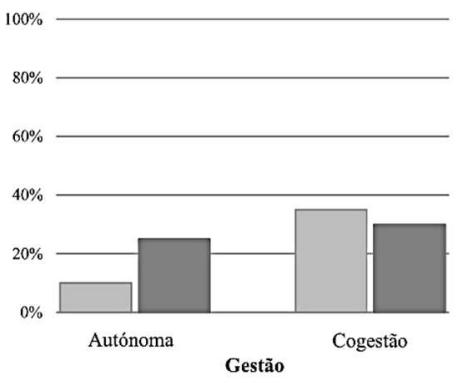

Entidade

$\square$ Conselho

Diretivo

Freguesia

Figura 1 - Distribuição das modalidades de gestão dos baldios em 2013 (GERMANO, 2013) (a) e na Base de Dados dos PUB (b)

\section{Análise estatística}

A hipótese de base deste estudo era a de que o tipo de modalidade de gestão poderia influenciar a qualidade de governança dos terrenos comunitários e dos seus recursos. Assim, a avaliação das variáveis dos primeiros quatro grupos foi realizada através de análises de variância para avaliação dos efeitos dos fatores relacionados com o tipo de gestão (autónoma ou cogestão), entidade (Conselho Diretivo ou Junta Freguesia) e sua interação.

Os gráficos resultantes dessas análises foram elaborados com o auxílio do software SPSS.

O quinto e último grupo de variáveis, devido a uma detalhada e volumosa descrição qualitativa das "Aptidões Gerais" e das "Estratégias de Gestão" dos baldios, foi avaliado de forma exploratória com recurso à técnica geradora de uma nuvem de "palavras" (também conhecida como wordle). Este método de análise permite extrair palavras-chave do texto analisado e atribuir-lhes um tamanho que depende da frequência com que estas aparecem. 


\section{Resultados e discussão}

Foi realizada uma análise de variância para cada uma das variáveis consideradas. Os resultados desta análise podem ser consultados no Quadro 3, organizados pelos grupos de variáveis anteriormente estabelecidos. A seguir, apresenta-se a discussão dos resultados destas análises, dando-se uma especial atenção às variáveis com diferenças estatisticamente significativas entre as modalidades de gestão.

Quadro 3 - Resultados gerais da análise de variância univariada na comparação das médias das quatro principais modalidades de gestão dos terrenos comunitarios, analisadas neste estudo, nomeadmente: baldios geridos por Conselhos Diretivos ou Juntas Freguesias em Gestão Autonoma (CD-GA e JF-GA) ou em Co-Gestão com Estado (CD-CG e JF-CG respetivamente)

\begin{tabular}{|c|c|c|c|c|c|c|c|c|c|c|c|}
\hline \multirow{3}{*}{ Variáveis analisadas } & \multirow{3}{*}{$\begin{array}{l}\text { Média } \\
\text { geral }\end{array}$} & \multirow{2}{*}{\multicolumn{4}{|c|}{ Médias por modalidade de gestão }} & \multicolumn{6}{|c|}{ Resultados da análise de variância univariada } \\
\hline & & & & & & \multicolumn{2}{|c|}{ Gestão } & \multicolumn{2}{|c|}{ Entidade } & \multicolumn{2}{|c|}{ Gestão $x$ Entidade } \\
\hline & & CD-GA & $\begin{array}{l}\text { JF- } \\
\text { GA }\end{array}$ & $\begin{array}{l}\text { CD- } \\
\text { CG }\end{array}$ & $\begin{array}{l}\text { JF- } \\
\text { CG }\end{array}$ & $\mathbf{F}$ & $\mathrm{p}$ & $\mathbf{F}$ & $\mathbf{p}$ & $\mathbf{F}$ & $\mathbf{p}$ \\
\hline \multicolumn{12}{|c|}{ Localização geográfica e administração } \\
\hline Área do badio (ha) & 432 & 324 & 225 & 560 & 491 & 24,95 & $0,000^{* *}$ & 2,806 & 0,094 & 0,084 & 0,772 \\
\hline Área submetidas ao Regime Florestal (\%) & 62 & 37 & 15 & 84 & 81 & 412,356 & $0,000^{* *}$ & 21,452 & $0,000^{* *}$ & 10,669 & $0,001 * *$ \\
\hline Baldios com litigios (\%) & 24 & 23 & 12 & 36 & 18 & 8,005 & $0,005^{* *}$ & 15,589 & $0,000^{* *}$ & 0,898 & 0,344 \\
\hline Número de assembleias por ano & 1,1 & 1,6 & 1,4 & 1,8 & 1,4 & 0,231 & 0,631 & 5,885 & $0,016^{*}$ & 0,306 & 0,580 \\
\hline Participação dos compartes & 25 & 36 & 27 & 38 & 42 & 4,672 & $0,031^{*}$ & 0,602 & 0,438 & 2,493 & 0,115 \\
\hline Realização de contas anuais (\%) & 67 & 65 & 60 & 70 & 71 & 3,752 & 0,053 & 0,146 & 0,703 & 0,669 & 0,414 \\
\hline Apresentação de contas anuais (\%) & 70 & 69 & 55 & 77 & 73 & 9,597 & $0,002^{*}$ & 4,835 & $0,028^{*}$ & 1,376 & 0,241 \\
\hline Investimentos nos últimos 5 anos $(\%)^{*}$ & 39 & 39 & 30 & 38 & 46 & 11,740 & $0,001^{* *}$ & 16,964 & $0,000^{* *}$ & 10,223 & $0,001^{* *}$ \\
\hline Apoio técnico (\%) & 98 & 97 & 99 & 97 & 98 & 0,002 & 0,968 & 1,382 & 0,240 & 0,092 & 0,762 \\
\hline Apoio jurídico (\%) & 18 & 18 & 12 & 26 & 11 & 1,059 & 0,304 & 7,882 & $0,005^{*}$ & 1,844 & 0,175 \\
\hline Apoio contabilistico (\%) & 43 & 29 & 55 & 33 & 50 & 0,041 & 0,840 & 21,703 & $0,000^{* *}$ & 0,943 & 0,332 \\
\hline \multicolumn{12}{|c|}{ Recursos florestais } \\
\hline Número de parcelas & 19 & 16 & 14 & 21 & 22 & 17,661 & $0,000^{* *}$ & 0,218 & 0,640 & 0,915 & 0,390 \\
\hline Número de parcelas com atividades agroflorestais & 14 & 13 & 10 & 15 & 16 & 7,073 & $0,008^{* *}$ & 1,309 & 0,253 & 3,938 & $0,048^{*}$ \\
\hline Ocupação por pinheiros (\%) & 60 & 62 & 50 & 61 & 67 & 5,398 & $0,020^{*}$ & 0,822 & 0,365 & 7,799 & $0,005 * *$ \\
\hline Ocupação por folhosas (\%) & 44 & 53 & 52 & 40 & 40 & 14,012 & $0,000^{* *}$ & 0,020 & 0,888 & 0,015 & 0,902 \\
\hline Quercus robur (\%) & 12 & 21 & 12 & 7 & 10 & 16,076 & $0,000^{* *}$ & 2,240 & 0,135 & 6,442 & $0,011^{*}$ \\
\hline Quercus suber $(\%)$ & 4 & 4 & 6 & 3 & 3 & 2,284 & 0,131 & 0,434 & 0,510 & 0,999 & 0,318 \\
\hline Pinus pinaster (\%) & 38 & 44 & 35 & 33 & 40 & 1,672 & 0,196 & 0,101 & 0,751 & 9,671 & $0,002^{*}$ \\
\hline Castanea sativa (\%) & 6 & 10 & 8 & 5 & 4 & 11,013 & $0,001^{* *}$ & 1,457 & 0,228 & 0,276 & 0,599 \\
\hline Eucalyptus ssp (\%) & 4 & 5 & 3 & 2 & 4 & 1,276 & 0,259 & 0,015 & 0,903 & 3,307 & 0,069 \\
\hline Ulmus ssp $(\%)$ & 0,7 & 0,5 & 0,5 & 0,4 & 1,3 & 0,508 & 0,476 & 0,790 & 0,374 & 0,807 & 0,369 \\
\hline Betula ssp (\%) & 2,7 & 1,7 & 2,1 & 3,6 & 2,6 & 1,913 & 0,167 & 0,121 & 0,728 & 0,587 & 0,444 \\
\hline Acer ssp (\%) & 3,0 & 3,0 & 2,2 & 2,7 & 3,7 & 0,542 & 0,462 & 0,032 & 0,858 & 1,461 & 0,227 \\
\hline Cupressus lusitanica (\%) & 2,4 & 3,4 & 2,2 & 1,5 & 3,3 & 0,272 & 0,602 & 0,121 & 0,728 & 3,315 & 0,069 \\
\hline Alnus glutinosa (\%) & 1,1 & 0,5 & 2,9 & 0,2 & 0,8 & 4,251 & $0,040^{*}$ & 6,743 & $0,010^{* *}$ & 2,763 & 0,097 \\
\hline Fraxinus angustifolia (\%) & 2,5 & 2,4 & 4,0 & 1,7 & 2,2 & 2,289 & 0,131 & 1,613 & 0,205 & 0,506 & 0,477 \\
\hline
\end{tabular}


102 Skulska, I., Monteiro, M.L. e Rego, F.C.

Quadro 3 - Cont.

\begin{tabular}{|c|c|c|c|c|c|c|c|c|c|c|c|}
\hline \multicolumn{12}{|c|}{ Condução operacional desenvolvida } \\
\hline Povoamentos puros (\%) & 67 & 67 & 63 & 69 & 67 & 0,618 & 0,432 & 0,920 & 0,338 & 0,111 & 0,739 \\
\hline Povoamentos regulares $(\%)$ & 57 & 62 & 46 & 62 & 58 & 2,829 & 0,093 & 9,694 & $0,002^{* *}$ & 3,413 & 0,065 \\
\hline Parcelas arborizadas (\%) & 22 & 17 & 25 & 20 & 25 & 0,358 & 0,550 & 6,548 & $0,011^{*}$ & 0,224 & 0,636 \\
\hline Sementeira (\%) & 2 & 3 & 1 & 2 & 3 & 0,292 & 0,589 & 0,059 & 0,808 & 3,576 & 0,059 \\
\hline Regeneração natural (\%) & 12 & 9 & 15 & 11 & 11 & 0,230 & 0,632 & 4,305 & $0,038^{*}$ & 3,635 & 0,057 \\
\hline Adensamento (\%) & 12 & 12 & 15 & 11 & 10 & 3,531 & 0,061 & 0,311 & 0,577 & 1,667 & 0,197 \\
\hline Reconversão (\%) & 3 & 5 & 4 & 2 & 3 & 8,197 & $0,004^{* *}$ & 0,071 & 0,790 & 1,9646 & 0,163 \\
\hline Limpezas (\%) & 34 & 36 & 44 & 31 & 35 & 3,628 & 0,057 & 3,404 & 0,065 & 0,241 & 0,624 \\
\hline Limpeza de matos (\%) & 37 & 41 & 44 & 37 & 38 & 1,739 & 0,188 & 0,344 & 0,558 & 0,221 & 0,638 \\
\hline Exploração / Corte de árvores (\%) & 8 & 10 & 5 & 10 & 7 & 0,381 & 0,538 & 9,223 & $0,002 * *$ & 0,819 & 0,366 \\
\hline Controlo de invasoras (\%) & 4 & 6 & 4 & 2 & 5 & 1,064 & 0,303 & 0,121 & 0,728 & 4,273 & $0,039^{*}$ \\
\hline Queimadas (\%) & 2 & 1 & 4 & 1 & 3 & 0,007 & 0,932 & 3,763 & 0,053 & 0,114 & 0,736 \\
\hline Equipa dos sapadores (\%) & 18 & 7 & 16 & 18 & 24 & 6,644 & $0,010^{* *}$ & 3,556 & 0,060 & 0,300 & 0,584 \\
\hline Fogo controlado (\%) & 6 & 7 & 10 & 5 & 6 & 1,509 & 0,220 & 0,546 & 0,460 & 0,204 & 0,652 \\
\hline \multicolumn{12}{|c|}{ Outros recursos dos baldios } \\
\hline Presença de pastagens (\%) & 80 & 85 & 81 & 75 & 85 & 0,612 & 0,434 & 0,516 & 0,473 & 2,995 & 0,084 \\
\hline Número de pastagens por baldio & 5 & 4 & 4 & 5 & 6 & 2,516 & 0,114 & 0,301 & 0,584 & 0,001 & 0,971 \\
\hline Caça (\%) & 91 & 89 & 91 & 91 & 91 & 0,112 & 0,738 & 0,135 & 0,713 & 0,018 & 0,892 \\
\hline Cogumelos (\%) & 49 & 36 & 46 & 59 & 44 & 5,311 & $0,022^{*}$ & 0,349 & 0,555 & 7,833 & $0,005^{* *}$ \\
\hline Pesca $(\%)$ & 39 & 29 & 32 & 43 & 38 & 1,831 & 0,176 & 0,006 & 0,937 & 3,992 & $0,046^{*}$ \\
\hline Apicultura (\%) & 29 & 24 & 28 & 33 & 27 & 1,024 & 0,312 & 0,113 & 0,737 & 1,599 & 0,207 \\
\hline Recreação (\%) & 44 & 39 & 38 & 45 & 50 & 3,804 & 0,052 & 0,296 & 0,587 & 0,558 & 0,455 \\
\hline Número de pedreiras & 0,3 & 0,12 & 0,26 & 0,37 & 0,26 & 0,957 & 0,328 & 0,017 & 0,896 & 0,902 & 0,343 \\
\hline $\begin{array}{l}\text { Torres de comunicações (TMN, Vodafone, TV, } \\
\text { radio, etc.) (\%) }\end{array}$ & 12 & 12 & 7 & 10 & 17 & 0,899 & 0,343 & 0,030 & 0,862 & 1,756 & 0,186 \\
\hline Eólicas $(\%)$ & 18 & 12 & 6 & 23 & 22 & 16,952 & $0,000^{* *}$ & 1,420 & 0,234 & 0,362 & 0,548 \\
\hline Número de eólicas & 0,7 & 0,2 & 0,1 & 0,9 & 1,0 & 11,569 & $0,001^{* *}$ & 0,002 & 0,968 & 0,269 & 0,604 \\
\hline Arrendamentos florestais (\%) & 4 & 6 & 9 & 1 & 4 & 8,761 & $0,003^{* *}$ & 2,424 & 0,120 & 0,001 & 0,970 \\
\hline \multicolumn{12}{|c|}{ Infraestruturas } \\
\hline Rede viária (\%) & 95 & 92 & 93 & 96 & 97 & 4,083 & $0,044^{*}$ & 0,182 & 0,670 & 0,001 & 0,974 \\
\hline Manutenção da rede viária (\%) & 40 & 40 & 41 & 42 & 43 & 0,302 & 0,583 & 0,128 & 0,721 & 0,013 & 0,910 \\
\hline Rede divisional (\%) & 44 & 42 & 43 & 42 & 45 & 0,177 & 0,674 & 0,255 & 0,614 & 0,042 & 0,838 \\
\hline Número de pontos de água & 1,0 & 0,9 & 0,9 & 1,2 & 1,2 & 3,884 & $0,049 *$ & 0,013 & 0,908 & 0,023 & 0,098 \\
\hline Manutenção dos pontos de água (\%) & 50 & 37 & 31 & 76 & 40 & 0,808 & 0,369 & 0,586 & 0,444 & 0,327 & 0,568 \\
\hline Casas da guarda-florestal (\%) & 37 & 27 & 25 & 52 & 46 & 29,769 & $0,000^{* *}$ & 0,838 & 0,360 & 0,202 & 0,654 \\
\hline
\end{tabular}

${ }^{*} \mathrm{p}<0,05$

$\begin{array}{rl}p & <0,05 \\ * * & p<0,01\end{array}$

: Investimentos nos últimos 5 anos, antes de 2007

\section{Administração}

\section{Áreas dos baldios, localização geográfica e Regime Florestal}

Os baldios analisados neste estudo estão localizados no Norte e no Centro de Portugal. Desses, 33\% encontram-se localizados no distrito de Vila Real, e correspondem a $38 \%$ da área total analisada. Quanto à área de cada um dos baldios, esta varia muito, numa escala que vai de 2,8 hectares (Baldio de Estadela, no distrito Braga) até 5349 hectares (baldio de São Pedro, no distrito da Guarda). A área média dos baldios do Norte é 414 hectares e do Centro é 508 hectares. 
Estas médias identificadas vão ao encontro de estudos anteriores. Verifica-se, de facto, que os baldios do Continente reservados provisoriamente pela JCI em 1938, tinham, em média, 439 hectares (MA, 1939). Já os analisados na região Norte por BAPTISTA et al. (2002) apresentavam uma média de 564 hectares.

A distribuição da área média entre as modalidades de gestão merece especial atenção (Figura 2). A diferença entre os baldios geridos em conjunto com o Estado é muito significativa, com uma área média muito superior (Figura 2a) e uma percentagem incluida em Regime Florestal também muito superior (Figura $2 b$ ). Estas diferencas entre os tipos de gestão são estatisticamente muito significativas (Quadro 3).

a)

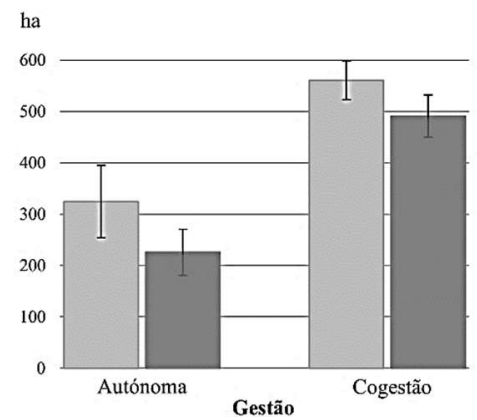

b)

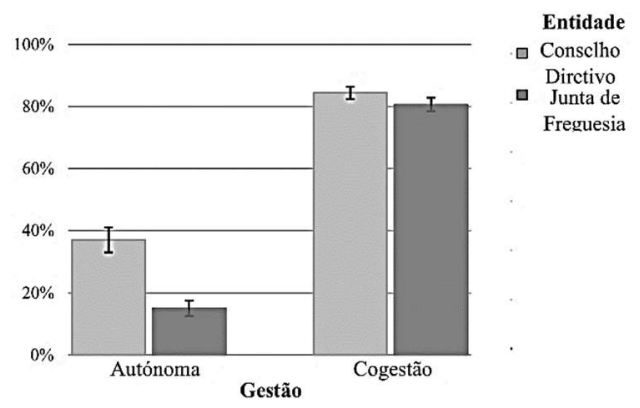

Figura 2 - Área média das diferentes modalidades baldias analisadas (a) e percentagem em Regime Florestal (b)

De notar a semelhança nos dois gráficos da Figura 2 no que respeita a áreas médias e percentagem em Regime Florestal. O facto de os baldios com maior área e maior percentagem de ocupação florestal serem geridos em cogestão com o Estado pode ser explicado pelo contexto histórico. As áreas submetidas ao Regime Florestal tinham sido objeto de florestação por parte dos Serviços Florestais e constituem já uma fonte de rendimento relevante. Assim, quando os povos recuperaram a posse desses baldios optaram naturalmente pela cogestão com o Estado.

A menor área de submissão ao Regime Florestal foi detetada nos baldios geridos por JF-GA. Estas áreas correspondem, possivelmente, a um menor interesse pelos compartes após a sua devolução, pelo que a partir dos anos 1990s a sua gestão foi assegurada por autarquias locais. 


\section{$\underline{\text { Funcionamento das Assembleias de Compartes }}$}

O quadro legal de 1976 (Decreto-Lei n. ${ }^{\circ}$ 39/76) permitiu concretizar a devolução dos terrenos baldios às comunidades locais. Para os povos poderem retomar a posse dos seus terrenos, foi exigida a sua organização sob a forma de Assembleias de Compartes (artigo $18^{\circ}$ ) devendo ser estas constituídas por moradores de determinada freguesia (ou parte dela) que, de forma comunitária e igualitária, usaram e fruíram, de acordo com os usos e costumes locais, os respetivos terrenos baldios (AFN, 2010). Entre as responsabilidades de maior importância da primeira Assembleia de Compartes estava a eleição de um Conselho Diretivo (CD) e a escolha de uma modalidade para a administração: exclusivamente pelos compartes ou em regime de associação entre os compartes e o Estado (alíneas a e b do art..$^{\circ}$ 9. $^{\circ}$ do Decreto-Lei n. ${ }^{\circ}$ 39/76 de 19 de janeiro).

A análise dos PUB mostrou que a constituição das primeiras assembleias começou logo em 1974 (Figura 3). O maior número de assembleias constituídas ocorreu em 1976 - ano da publicação do Decreto-Lei n. ${ }^{\circ}$ 39/76 - e em 1995, dois anos depois da publicação da Lei dos Baldios n. ${ }^{\circ}$ 68/93. A Lei de 1993 deu às comunidades que tinham dificuldade em criar a sua primeira Assembleia de Compartes a possibilidade de delegar o direito de administração do seu baldio à respetiva Junta de Freguesia (JF). Além disso, a administração de alguns baldios, sobretudo nas zonas metropolitanas do Porto e de Lisboa passou a ser assegurada pelos Serviços Florestais.

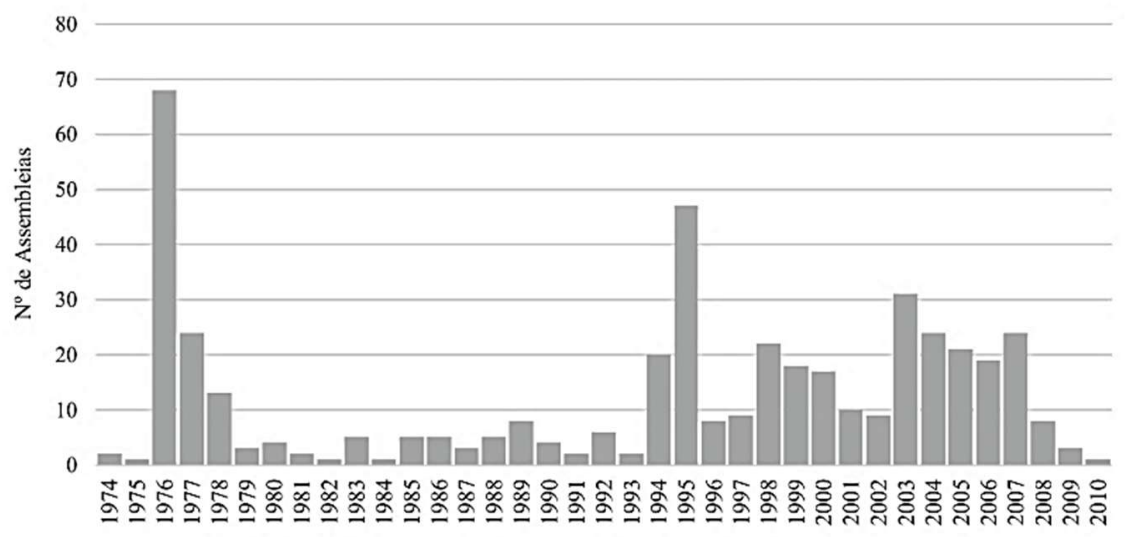

Figura 3 - Evolução da constituição das primeiras Assembleias de Compartes 
A partir da constituição das Assembleias de Compartes foram definidas as modalidades de administração dos baldios que foram evoluindo até aos dias de hoje, predominando a administração em associação com o Estado (AFN, 2010; GERMANO, 2013).

A questão da frequência e participação dos compartes nas assembleias foi também objeto de análise (Figura 4). Em geral, as médias de participação são baixas (entre 9 e 34 presentes). No entanto, no seu estudo, BAPTISTA et al. (2002) não consideram que esta fraca participação nas Assembleias seja um problema, "...já que estes [compartes] exercem, com frequência, uma vigilância difusa mas crítica que, muitas vezes, emerge em rumores e "falatórios" sobre o destino do baldio." Também SERRA et al. (2018) não valorizam apenas formas de aumentar a participação dos compartes, mas enfatizam sobretudo a importância de integrar jovens (a próxima geração de compartes) nessa participação.

Os resultados da nossa análise demonstraram que, em média, em cada baldio ocorre mais de uma convocação dos compartes por ano (Figura 4a) e a presença média dos compartes nestas reuniões é de 25 participantes (Figura 4b).

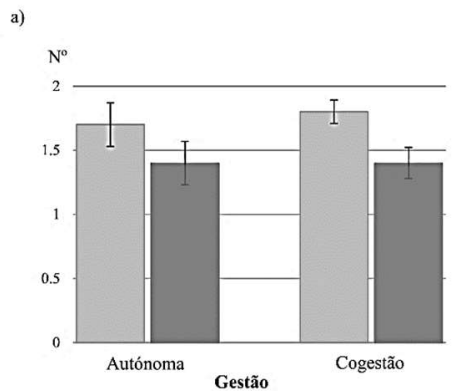

b)

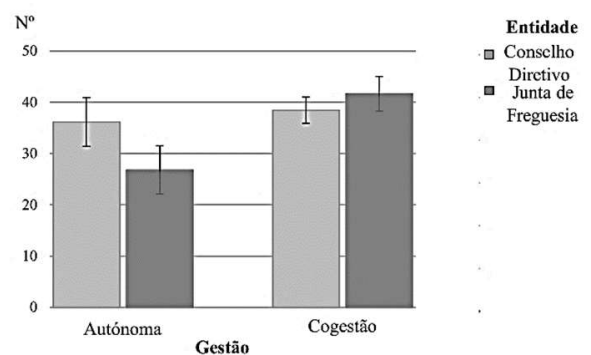

Figura 4 - Número médio de assembleias por ano (a) e participação média dos compartes (b)

Verifica-se que existem diferenças significativas entre modalidades (Quadro 3). Nos baldios com Conselhos Diretivos as reuniões ocorreram com maior frequência. Relativamente à participação média nessas reuniões, de acordo com a análise estatística, o tipo de gestão afeta o número de participantes, sendo ligeiramente maior em baldios em cogestão. 


\section{Apresentação de contas}

A gestão dos baldios está sujeita ao regime de normalização contabilística. $\mathrm{O}$ dever da entidade gestora dos baldios de apresentar as contas anuais e o relatório das atividades, relativos ao exercício do ano anterior à Assembleia de Compartes é indicado em todas as leis dos baldios, aprovadas desde 1976. A análise dos PUB mostrou que, em média, 67\% dos baldios realizam estas contas e 70\% apresentam-nas (Figura 5). Essa diferença de 3\% pode ser explicada pela ausência na obtenção de receitas, bem como pelas diferenças no método de apresentação das contas anuais (escrita ou oral).
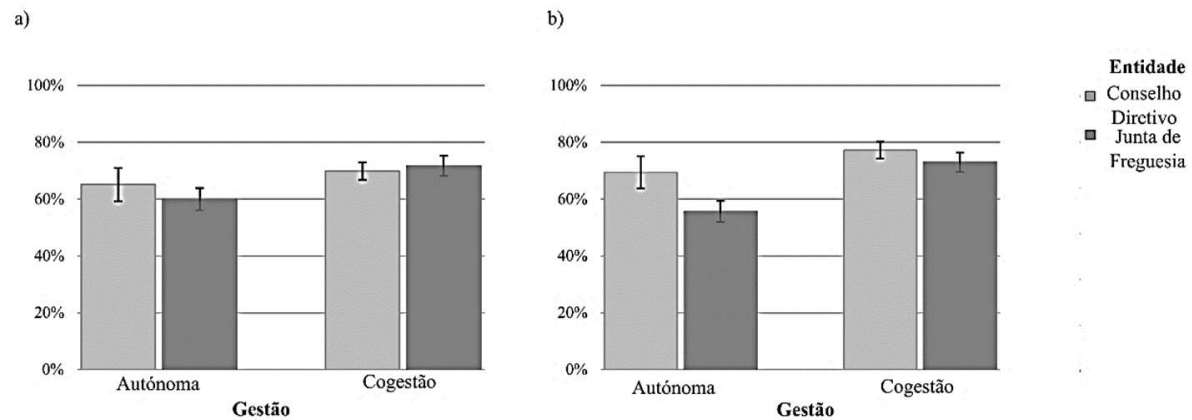

Figura 5 - Realização de contas anuais (a). Apresentação das contas (b)

Embora a realização de contas não demonstre nenhuma relação significativa com o tipo de gestão ou entidade, pode referir-se que a apresentação de contas dos baldios difere significativamente entre modalidades (Quadro 3). Os baldios geridos por Conselhos Diretivos apresentam contas em maior percentagem do que os geridos por Juntas de Freguesia. Provavelmente, por nos casos em que os baldios são geridos por JF as receitas dos baldios serem consideradas como fonte de receitas adicionais e diluídas depois no orçamento geral. Desta forma, as receitas obtidas destes baldios, poderem ser aplicadas numa outra parte da freguesia, o que contradiz as regras do seu investimento ou distribuição (SKULSKA et al., 2017). Há também percentagens maiores de apresentação de contas nos baldios em cogestão. 
$\underline{\text { O investimento nas áreas baldias }}$

Segundo o art. $14^{\circ}$ da Lei dos Baldios $n^{\circ} 75 / 2017$, as receitas obtidas com a exploração dos recursos dos baldios não são distribuíveis, mas devem ser investidas na valorização económica desses territórios e em benefício das respetivas comunidades. As regras de distribuição de receitas estão presentes em todas as leis dos baldios, mas o montante mínimo de investimento na constituição de reservas para a sua futura valorização ( $20 \%$ dos rendimentos) só foi especificado na última lei aplicável.

A análise mostra que, em média, nos 5 anos anteriores à elaboração do PUB, apenas $40 \%$ dos baldios executaram os investimentos, havendo diferenças muito significativas entre modalidades (Quadro 3) e havendo interações significativas entre os dois fatores, sendo os maiores investimentos realizados pelas JF em cogestão e os menores investimentos pelas JF em gestão autónoma (Figura 6).

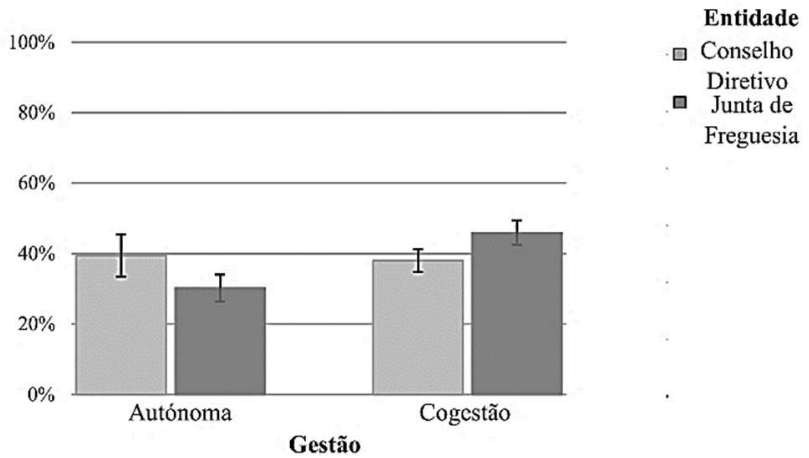

Figura 6 - Percentagem de investimentos executados nos últimos 5 anos, antes de 2006

Segundo a avaliação realizada por SKULSKA et al. (2020), a questão dos investimentos nos baldios em cogestão continua a ser de difícil resolução, já que os SF enquanto cogestores não participam nesta tarefa. Consequentemente, os investimentos em terrenos baldios com gestão autónoma tendem a ser mais frequentes e maiores, o que não coincide com os resultados desta análise. $\mathrm{Na}$ mesma avaliação, os administradores de baldios em cogestão indicaram como objetivos de investimento a restauração de florestas, a limpeza dos matos, a reparação de caminhos e a abertura de novos acessos. 
Os frequentes e severos incêndios florestais levaram ao desinteresse dos compartes quanto à gestão das áreas florestais e aumentaram a intenção de adotar outro tipo de uso do solo (SKULSKA et al., 2017). Os estudos de COPENA (2018) apontam que novas atividades económicas, desenvolvidas em alguns baldios, nomeadamente a instalação dos parques eólicos, aumentaram as receitas destes.

Parece interessante investigar a fração do investimento destas receitas na gestão florestal das áreas baldias.

\section{$\underline{\text { Apoio técnico, jurídico e contabilístico }}$}

A procura de apoio técnico foi detetada na maioria dos PUB sem diferença significativa entre o tipo de gestão ou entidade gestora (Quadro 3). A silvicultura é uma atividade complexa, que envolve planos de gestão de longa duração e requer geralmente um tipo específico de conhecimento. Um papel meritório no apoio técnico aos baldios está a ser desenvolvido por algumas Associações, centradas na maioria no Norte de Portugal. O desenvolvimento e o apoio do número de associações especializadas na gestão de recursos florestais baldios é de extrema importância, sobretudo no Centro de Portugal (SKULSKA et al., 2017).

O apoio jurídico é o mais procurado em baldios administrados pelo modelo $\mathrm{CD}$, (Figura 7a), e relaciona-se possivelmente, por um lado, com conflitos antigos destes terrenos e, por outro, com o facto de os compartes destas modalidades serem mais ativos na luta pelos seus direitos. Salienta-se que na resolução de litígios envolvendo áreas baldias em cogestão o apoio jurídico prestado por instituições estatais é escasso ou mesmo ausente, situação que permanece (SKULSKA et al., 2017).

O apoio contabilístico é o mais recorrente nos baldios administrados por JF (Figura $7 b$ ). Isto estará relacionado com o quadro de funcionários desta entidade, apesar de ser obrigatória por legislação a presença de um membro no Conselho Diretivo responsável pelo relatório e as contas de cada exercício, bem como a proposta de aplicação das receitas. 

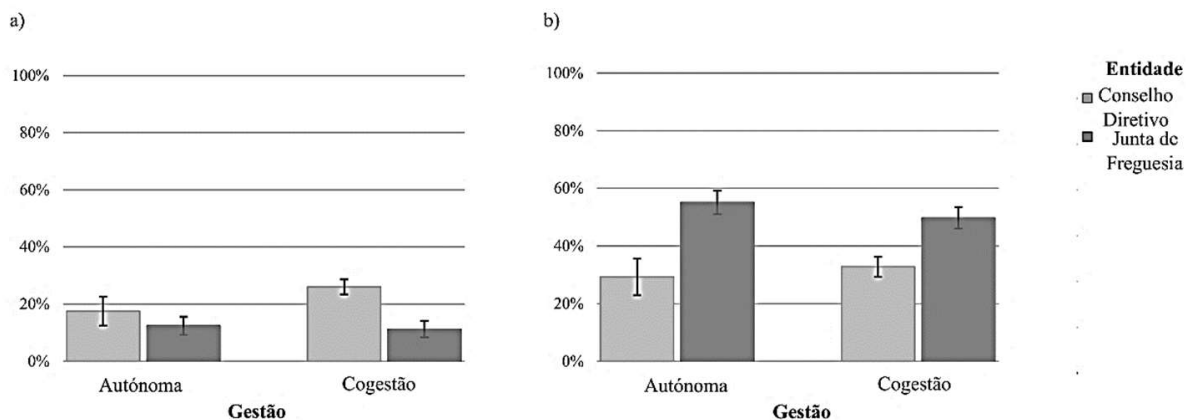

Figura 7 - Procura de apoio jurídico (a) e contabilístico (b)

\section{Recursos e atividades florestais}

Devido à arborização que foi promovida pelo Estado nas áreas submetidas a Regime Florestal, a floresta assume hoje um grande relevo nos baldios (AFN, 2010). Não obstante, vários estudos apontarem para uma redução significativa da área florestal nesses territórios nas últimas décadas (REGO, 2001; PINHO et al., 2012; SKULSKA et al., 2020). Nesta parte do estudo analisamos os principais componentes dessa que é uma parte integrante da economia dos baldios para entender a relação entre o seu estado atual e as modalidades de gestão.

A análise dos PUB demonstrou que o número de parcelas nas áreas baldias varia entre 1 e 165. Em média, os baldios estão divididos em 19 parcelas, 14 de quais $(74 \%)$ costumam ser dedicadas a atividades agroflorestais, não revelando a sua quantidade diferenças significativas no tipo de gestão, nem na entidade administrativa (Quadro 3).

\section{Composição da floresta}

No que respeita à composição das florestas nestas áreas, verifica-se que os pinheiros estão presentes em média em $60 \%$ das parcelas baldias o que, de certa forma, é associado ao Regime Florestal. Esta asserção faz todo o sentido, uma vez que uma das razões para a aplicação do Regime foi a fixação do solo. Sendo conhecido que o solo, nas zonas com maior altitude, estava francamente degradado e erodido, a alternativa em termos de uso de espécies apontava para 
pioneiras, neste caso o pinheiro bravo (Pinus pinaster). Assim se justifica a predominância de resinosas, independentemente do tipo de gestão (Figura 8a).

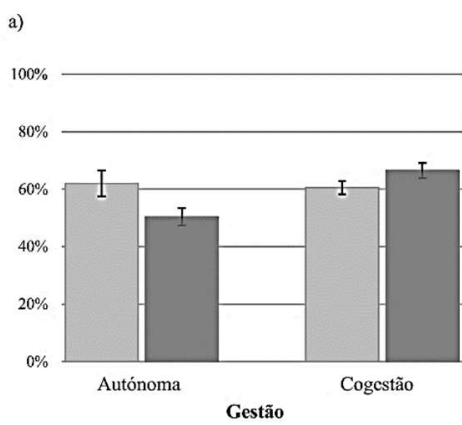

b)

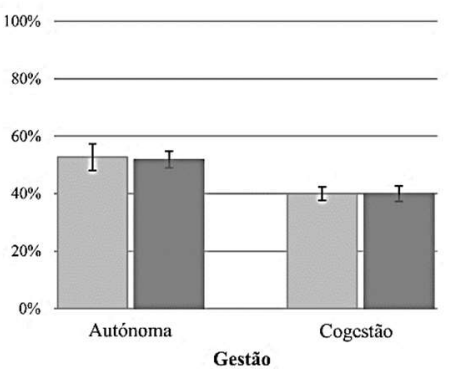

Figura 8 - Ocupação por pinheiros (a) e folhosas (b)

Após a Lei dos Baldios de 1976, à medida que o território era de novo utilizado pelos compartes e os projetos iam sendo concebidos, parece ter-se verificado outra atenção em relação a um uso mais diversificado de espécies. Esta situação poderá explicar o aumento da ocupação com folhosas. No entanto, esta instalação foi maior em modalidades de gestão autónoma (Figura 8b), uma vez que a burocracia era menor relativamente às modalidades em cogestão (SKULSKA et al., 2017). Por outro lado, talvez por uma menor influência do Regime Florestal muito focado na utilização do pinheiro bravo, as folhosas poderão ter tido maior possibilidade de recuperação natural.

Para os diferentes baldios, procedeu-se também à análise da distribuição das principais espécies folhosas existentes em mais de $40 \%$ das parcelas dos baldios. Como seria de esperar, em termos edafoclimáticos e de acordo com as grandes regiões de planeamento, as espécies mapeadas, apresentadas na Figura 9 estão maioritariamente bem instaladas. No que respeita ao Quercus robur, embora haja três concelhos em que os baldios têm uma ocupação com esta espécie superior a 60\% (Vieira do Minho, Terras de Bouro e Póvoa de Lanhoso), é sabido que existem condições para a expansão da sua área de ocupação no litoral Norte.

Quanto à Quercus pyrenaica (Figura 9b), é uma espécie que se mostra muito interessante no interior Norte e Beiras. É uma espécie autóctone com um forte potencial multiuso (p.e. caça, apicultura, cogumelos) e que deverá ser alvo de melhor gestão. Ainda na Figura 9c, verifica-se a distribuição da Quercus suber, embora em percentagens não muito altas (média geral de ocupação $4 \%$ ), mas, suficientemente consideráveis para ser uma espécie a ter em atenção em projetos 
futuros de reflorestação, sempre que os pressupostos exigidos pela espécie sejam satisfeitos.

a) Quercus robur

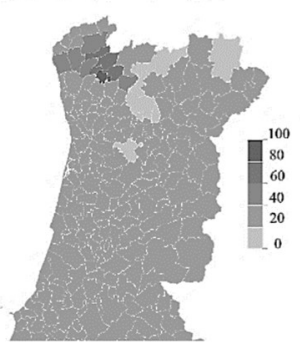

d) Pinus pinaster

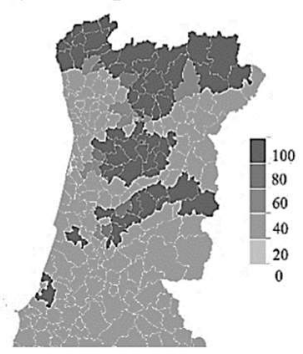

b) Quercus pyrenaica

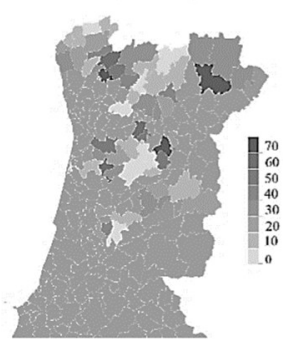

e) Castanea sativa

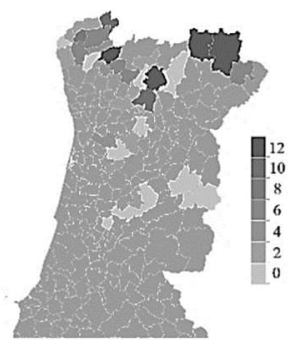

c) Quercus suber

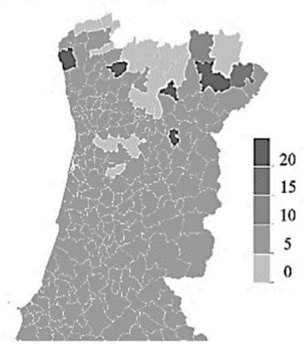

f) Eucalyptus globulus

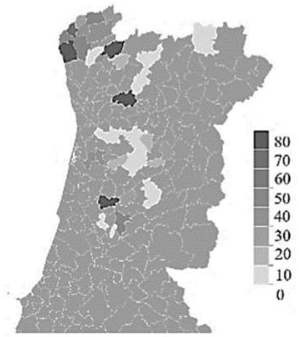

Figura 9 - Percentagem da ocupação de espécies em terrenos baldios por concelhos: Quercus robur (a), Quercus pyrenaica (b), Quercus suber (c), Pinus pinaster (d), Castanea sativa (e) e Eucalyptus globulus (f)

Analisando a Figura 9d e a ocupação do Pinus pinaster nas áreas baldias, podemos dizer que a presença desta essência é bastante significativa na maioria das unidades analisadas. Admite-se que a atual distribuição do pinheiro, como já foi acima abordado, faça sentido como pioneira, respondendo aos requisitos do Regime Florestal. No entanto, futuras intervenções nesta zona devem ter em atenção o uso de povoamentos mistos e de folhosas, sobretudo quando estamos em presença de solos frescos e fundos, nomeadamente nos vales e linhas de água, sem esquecer as ripícolas a usar também nestes espaços quando se justificar e, sobretudo nas margens de ribeiros e de rios.

Quanto à distribuição da Castanea sativa (Figura 9e), a ocupação apresentada é relativamente baixa para a possibilidade de expansão desta espécie (média geral de ocupação 6\%), tendo em conta, segundo MONTEIRO (2000), os 
parâmetros exigidos pelo castanheiro, bem como o seu valor económico, social e paisagístico.

A espécie Eucalyptus globulus (Figura 9f) mostra uma presença acentuada somente em alguns baldios dos concelhos de Terras de Bouro, Amarante, Penacova e Viana do Castelo, embora a média geral de ocupação desta espécie, nos baldios analisados à escala nacional, não ultrapasse os $4 \%$.

\section{Condução cultural de povoamentos florestais}

A condução dos povoamentos tem como objetivo manter e melhorar o potencial produtivo dos mesmos, através de operações culturais no povoamento ou na vegetação concorrente com estes.

A atual gestão das áreas florestais baldias não é apenas um tipo de atividade económica relacionada com a reprodução das florestas, mas também uma ferramenta essencial para a conservação e proteção dos terrenos montanhosos. Apesar do grande número de desacordos, e até conflitos, entre as entidades gestoras das áreas florestais baldias, estes gestores continuam a ser os aliados mais importantes na governança destes recursos.

A análise dos PUB mostrou que nas áreas florestais baldias predominam povoamentos puros (Figura 10a), pinhais ou eucaliptais, e também povoamentos regulares (Figura 10b), em que todas as árvores pertencem à mesma classe de idade ou em que a diferença entre a árvore mais nova e a mais velha não excede $20 \%$ da idade de revolução. A análise estatística mostrou que o tipo de entidade gestora afeta a proporção de povoamentos regulares, a maioria dos quais localizados em terrenos baldios geridos por $\mathrm{CD}$ (Quadro 3).

Quanto à arborização florestal dos baldios, esta é significativamente diferente entre as entidades (Figura 11a), podendo afirmar-se que as JF arborizam mais parcelas possivelmente, graças a um maior acesso a fundos. A arborização através de sementeiras é pouco frequente e independente das modalidades (Figura 11b).

Por outro lado, segundo dados de SKULSKA et al. (2020) os frequentes incêndios, problemas com doenças e pragas, cuja frequência aumentou nas últimas décadas, bem como a falta de conhecimento técnico e ambiental por parte dos gestores dos baldios reduz drasticamente o investimento nas plantações ou sementeiras de novas áreas florestais e no controlo de áreas regeneradas naturalmente. 


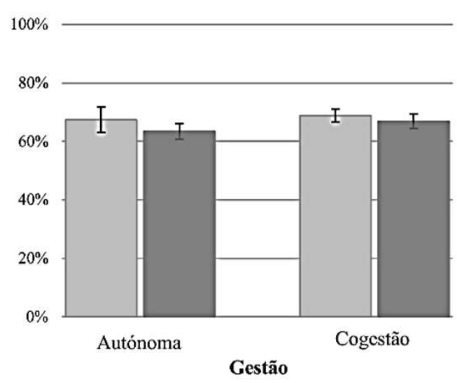

b)

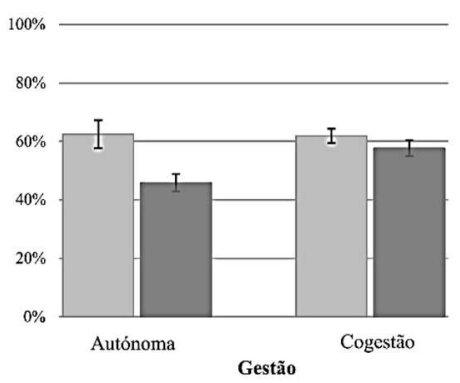

Entidade

$\square$ Conselho

Diretivo

Freguesia

Figura 10 - Percentagem de povoamentos puros (a) e de povoamentos regulares (b) por modalidade
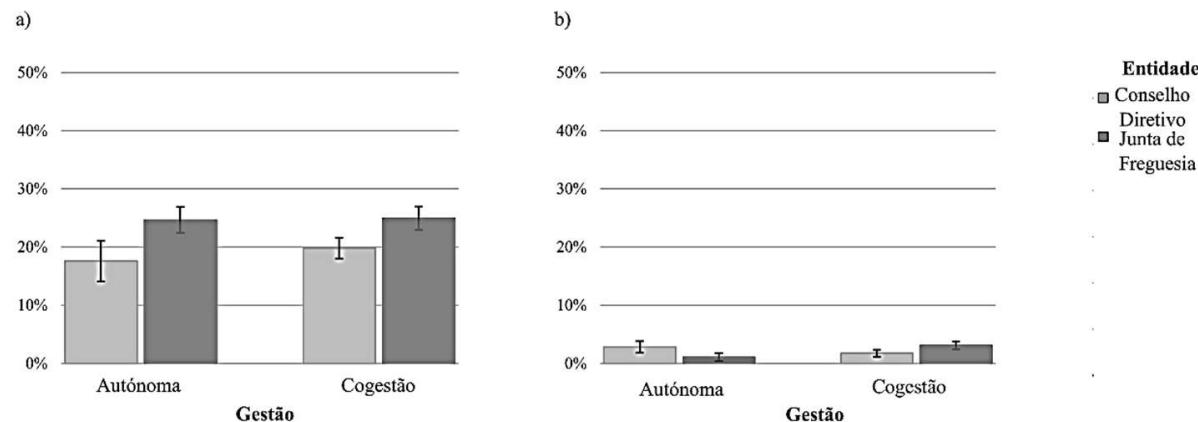

Figura 11 - Parcelas arborizadas com plantação (a) e com sementeira (b)

Quanto à regeneração natural, o seu valor é genericamente baixo, tendo sido superior nos baldios administrados por JF-GA, comparativamente com os geridos por outras entidades (Figura 12).

Este resultado é um pouco diferente dos resultados obtidos na avaliação de SKULSKA et al. (2017), onde não se constataram diferenças entre as modalidades no que respeita à regeneração natural. Os resultados daquela avaliação indicavam que nos últimos anos a regeneração tinha sofrido uma grande diminuição devido a vários fatores, como: (i) os incêndios florestais que, além de promoverem uma regeneração natural que posteriormente não vai ter qualquer tipo de gestão, poderão esgotar, para algumas espécies, o banco de sementes no solo; (ii) a execução de cortes rasos, e no caso de cortes seletivos, a escolha das melhores árvores (árvores dominantes e sementões) diminuiu a capacidade reprodutiva das áreas florestais; (iii) a deterioração das condições fitossanitárias das florestas devido à falta de conhecimentos técnicos na luta contra doenças e 
114 Skulska, I., Monteiro, M.L. e Rego, F.C.

pragas de espécies silvícolas; (iv) introdução e rápida ocupação de espécies invasoras lenhosas.

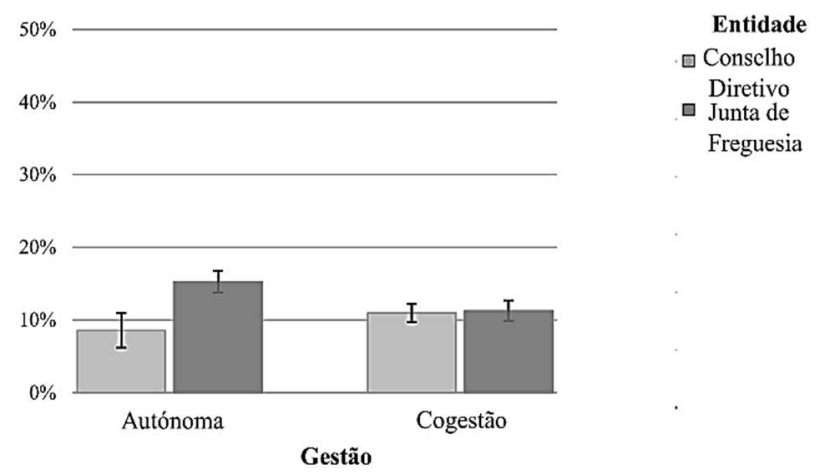

Figura 12 - Regeneração natural em parcelas baldias

Quanto à reconversão de povoamentos, os resultados indicam que a maior percentagem de povoamentos reconvertidos foi detetada em baldios com tipo de gestão: CD-GA (Figura 13a). Isso deve-se, provavelmente, ao maior interesse dos compartes na gestão dos seus terrenos e à menor burocracia dessa modalidade, em comparação com a de cogestão.
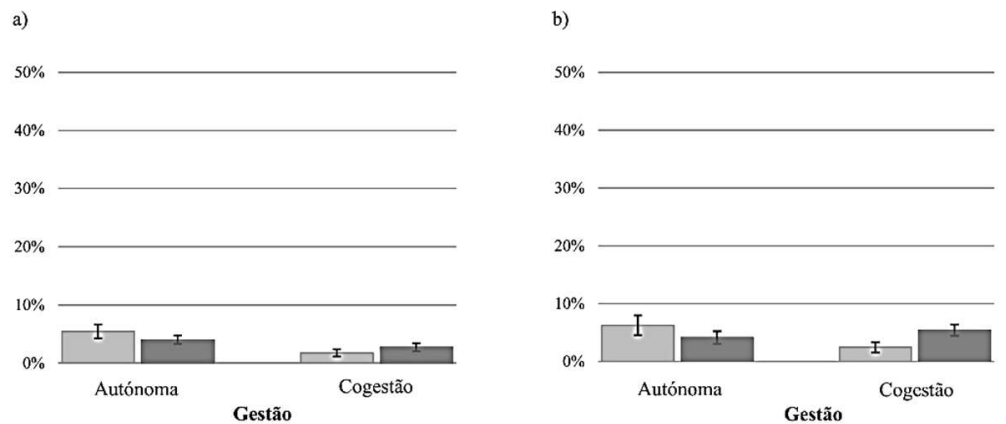

Figura 13 - Reconversão de povoamentos (a) e controlo de invasoras (b) por modalidade

O problema do controlo de invasoras é pouco valorizado. Apenas $4 \%$ dos baldios, em média, mostra alguma preocupação com este assunto (Figura 13b) e só dois baldios, em 664 analisados, incluem a luta contra invasoras na sua 
estratégia de gestão. Isto apesar de na avaliação SKULSKA et al. (2017) os gestores dos baldios reconhecerem este fenómeno como uma das principais ameaças às áreas florestais.

\section{Equipas de sapadores florestais e uso do fogo controlado}

As equipas de sapadores estão presentes, em média, em um quinto dos baldios, com predominância nos modelos de cogestão (Figura 14a). Há também uma tendência para que haja mais equipas de sapadores em baldios administrados por JF, o que poderá ser explicado pelo facto de este tipo de entidade estar melhor preparada para os concursos de atribuição de equipas sapadores e ter mais facilidade em financiar a parte que lhes compete, de acordo com Lei.
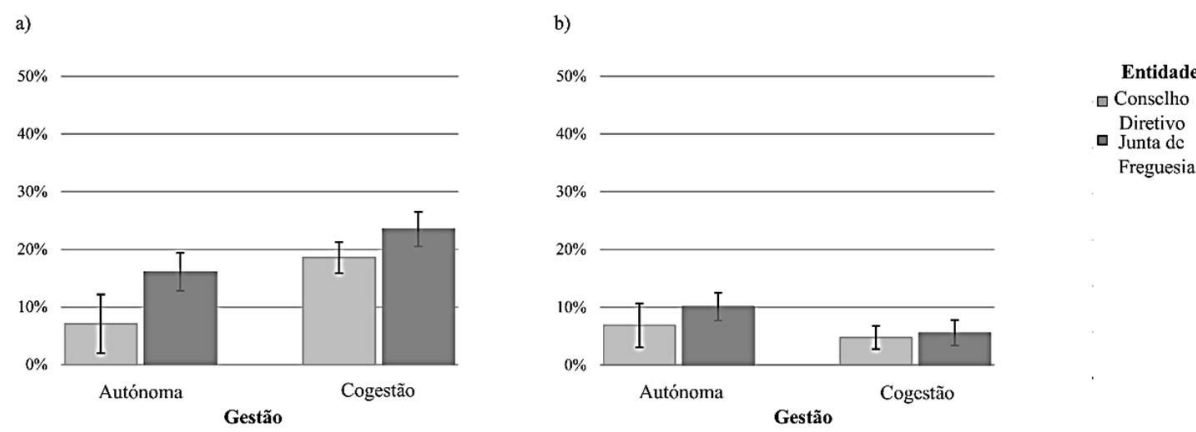

Figura 14 - Equipas de sapadores nos baldios (a) e a aplicação do fogo controlado (b)

Quanto ao fogo controlado, este tem globalmente uma baixa percentagem de aplicação não excedendo os 10\% em nenhuma modalidade (Figura 14b).

No geral, pode dizer-se que, como constatado no trabalho de avaliação de SKULSKA et al. $(2017,2020)$ a situação relativa ao nível de risco de incêndio, não é a desejável. Nessa avaliação concluía-se que, embora uma das maiores despesas dos baldios seja a contratação de equipas de sapadores, que por sua vez aumenta o número de empregos em zonas rurais, o serviço público prestado por essas equipas é limitado não incluindo, por exemplo, o controlo de combustível em áreas protegidas nem a reparação dos pontos de água. 
Outros recursos dos baldios

Os baldios que atualmente existem são objeto de várias formas de utilização, desde as mais tradicionais (pastoreio, caça, pesca, realização de culturas agrícolas anuais, apicultura ou recolha de cogumelos), que correspondem à economia individual dos compartes, até novas atividades económicas com receitas significativas para as comunidades que os gerem (como, por exemplo, parques eólicos, torres de comunicação ou arrendamento de áreas baldias para resinagem).

A exploração de diferentes recursos não lenhosos encontra-se numa fase incipiente. Alguns destes produtos são recolhidos para consumo próprio (como por exemplo cogumelos) e venda de outros, como por exemplo resina ou o arrendamento de terrenos baldios para parques eólicos, o que aumentou consideravelmente a receita de vários baldios. A exploração deste tipo de produto é sempre mais benéfica para as comunidades, pois as receitas não estão sujeitas a repartição com os $\mathrm{SF}$, nem a impostos.

Nas últimas décadas, em alguns dos baldios aumentou o interesse por cogumelos silvestres comestíveis com vantagem comercial, bem como pela exploração da castanha e de produtos provenientes da apicultura. Nas modalidades JF-CG e JF-GA estes produtos são muitas vezes recolhidos por terceiros. Como estas duas modalidades são geridas por entidades estatais existe a perceção, por parte da população, de que são áreas públicas de livre acesso. Além disso, a fragilidade da legislação e a falta de controlo exacerbam a situação (SKULSKA et al., 2017).

A variedade destes recursos e atividades é bastante ampla. A Figura 15 mostra a distribuição dos recursos mais representativos e as atividades que mais receitas proporcionam ou que são mais importantes para manter a vida das comunidades.

\section{$\underline{\text { Pastagens }}$}

As pastagens permanentes de montanha constituem um dos recursos mais importantes nos baldios. A sua cobertura vegetal é maioritariamente constituída por arbustos e matos (BAPTISTA, 2010). Em média, mais de $80 \%$ dos baldios analisados incluem pastagens dentro do seu limite, e o número pode variar de 1 a 30 pastagens / baldio. Atualmente, 12\% dessas pastagens não são utilizadas, enquanto $84 \%$ apresentam níveis de uso alto ou médio. 


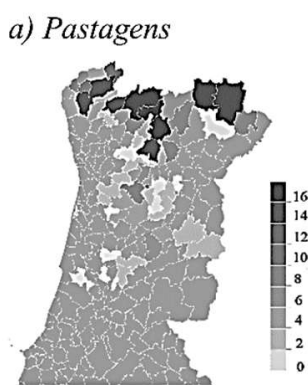

d) Pesca

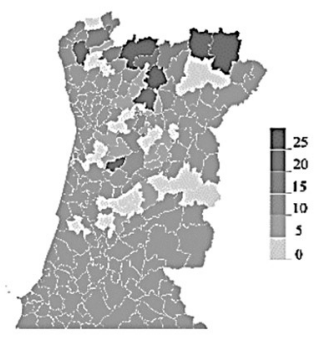

b) Caça

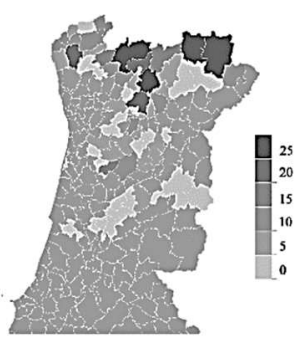

e) Apicultura

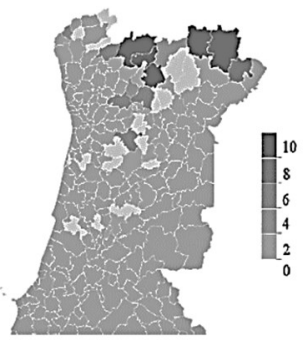

h) Eólicas

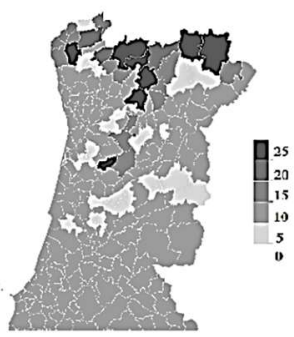

c) Cogumelos

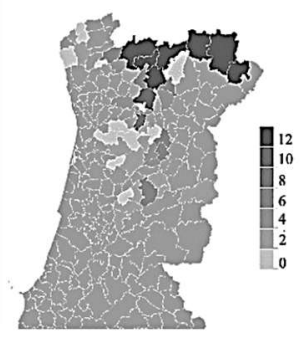

f) Recreação e lazer

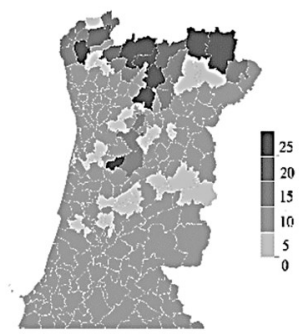

Figura 15 - Número de baldios por concelho que indicam a existência de recursos e de atividades não-silvícolas mais importantes: a) baldios com pastagens; b) baldios com atividades cinegéticas; c) baldios com exploração de cogumelos silvestres; d) baldios com atividade piscatória; e) baldios com apicultura; f) baldios com atividades de recreação e lazer; h) baldios com parques eólicos

O maior número de pastagens por baldio está localizado nos baldios em cogestão, onde predomina o Regime Florestal, uma vez que a Lei do Povoamento Florestal (Lei de 15 de julho de 1938) previa não apenas a florestação de 420 mil hectares de baldios, mas também o desenvolvimento e melhoramento de $60 \mathrm{mil}$ hectares de pastagens. 
A análise geral mostra que os pastos dos 600 baldios estudados são explorados para os seguintes tipos de gado (em milhares de cabeças e em unidades baldio): 1827,5 caprinos em 327 baldios; 70,7 ovinos em 360 baldios; 20,7 bovinos em 320 baldios e 9,1 equinos em 195 baldios.

Esta quantidade difere da relatada no inquérito de BAPTISTA et al. (2002), realizado apenas nos baldios do Norte de Portugal (Quadro 4) e demonstra o aumento da atividade pecuária dos baldios nas últimas décadas, com um aumento significativo de caprinos e ovinos.

Quadro 4 - Número médio de cabeças de bovinos, ovinos e caprinos nas freguesias com baldios

\begin{tabular}{|l|c|c|c|}
\hline \multirow{2}{*}{ Fonte de Informação } & \multicolumn{3}{|c|}{ Número Médio de Cabeças por Baldio } \\
\cline { 2 - 4 } & Bovinos & Ovinos & Caprinos \\
\hline Inquérito de BAPTISTA et al. (2002) & 59 & 52 & 67 \\
\hline Base de dados de PUB & 65 & 197 & 183 \\
\hline
\end{tabular}

O aumento de gado pode ser explicado pelo aumento de apoios dados pela PAC às ações de pastoreio nos últimos anos. Trata-se não só de uma atividade importante e com grande influência na regeneração da economia em zonas rurais, mas também de um serviço que permite manter os níveis de carga de combustível de modo a reduzir os custos de manutenção das redes de Defesa da Floresta Contra Incêndios.

\section{$\underline{\text { Caça e pesca }}$}

A caça pratica-se em $90 \%$ dos baldios analisados, $23 \%$ dos quais pertencem a zonas de caça municipal e os outros a zonas de caça associativa. As atividades cinegéticas praticam-se de forma frequente em $67 \%$ dos baldios.

A caça é igualmente explorada, quer em baldios em cogestão, quer em baldios com gestão autónoma. Admite-se que este resultado tenha por base o histórico de os povos terem tido sempre a possibilidade de caçar livremente. Na sua análise, BAPTISTA (2010) refere que, nos últimos anos, aumentou o número de casos em que a caça contribuiu para aumentar as receitas do baldio, e também as situações em que, por pressão dos Municípios, o baldio é um espaço de acesso livre às populações locais.

Quanto à pesca, esta pratica-se em média em $40 \%$ dos baldios e a sua execução não apresenta diferenças significativas entre tipos de gestão (Quadro 
3). Naturalmente, esta atividade estará mais relacionada com os recursos hídricos disponíveis em cada Unidade Baldia gerida.

\section{$\underline{\text { Cogumelos e apicultura }}$}

Quanto à prática de recolha de cogumelos, verifica-se que esta atividade é levada a cabo em quase metade dos baldios. As espécies mais procuradas são: boletos (Boletus ssp), sanchas (Lactarius deliciosus), míscaros (Tricholoma equestre), tortulhos (Macrolepiota procera) e rapazinhos (Cantharellus cibarius).

$\mathrm{Na}$ análise estatística foram notadas diferenças significativas entre as modalidades baldias no que respeita à colheita deste produto (Quadro 3). As médias mais elevadas observam-se nos baldios geridos por CD-CG e JF-GA. O primeiro caso pode ser explicado pelo interesse dos compartes na exploração direta dos recursos dos seus baldios. No segundo pode estar relacionado com o facto de os baldios serem considerados de acesso livre

Os cogumelos silvestres têm sido um produto subestimado, mas com enorme potencial. Na época de colheita, este produto rende milhares de euros a famílias rurais, mas a estimativa da sua produção permanece desconhecida, enquanto a sua venda (dentro do país ou para exportação) exige ser estudada. Atualmente, os gestores dos baldios autónomos, através do desenvolvimento de vários tipos de atividades (formações, caminhadas micológicas, etc.), procuram aumentar o interesse dos compartes por este tipo de produtos e pela gestão dos seus baldios em geral (SERRA, RODRIGUES e GARCÍA-BARRIOS, 2017).

Quando ao exercício de apicultura, este pratica-se num terço dos baldios, podendo o número de colónias chegar a mil. Este tipo de atividade não apresenta diferenças significativas entre as modalidades em estudo, devendo-se seguramente à disponibilidade de alimento

\section{$\underline{\text { Recreação e lazer }}$}

Entre $40 \%$ e $50 \%$ dos baldios desenvolvem algum tipo de lazer e recreio (piqueniques, percursos pedestres e/ou micológicos, BTT, escaladas e campos de paintball, entre outros). Em muitos destes casos existem mesmo infraestruturas de apoio. Este é um dos novos tipos de uso dado a terrenos baldios, e é bastante procurado por turistas e residentes urbanos. Esta procura, em algumas manchas e em certas épocas do ano, é muito intensa e algumas dessas atividades são 
organizadas informalmente, estando fora do controlo das comunidades locais. Frequentemente, os compartes nem são informados sobre a sua existência e, em muitos casos, estas atividades não trazem nenhum benefício para os rendimentos dos baldios (BAPTISTA, 2010; LUZ, 2017). Este é um recurso com grande potencial que poderá, se bem gerido, contribuir significativamente para o desenvolvimento local.

\section{Energia eólica e outras receitas}

Outra atividade importante que tem sido desenvolvida em terrenos baldios nas últimas décadas é o arrendamento do espaço para instalação de parques eólicos ou torres de comunicação (Vodafone, TV, Polícia, Radio, etc). Esta permite a obtenção de receitas elevadas durante 20 anos, sem qualquer investimento. Uma análise da AFN (2010) mostrou que aproximadamente 53\% da potência nacional instalada dos Parques Eólicos está localizada em territórios comunitários, graças à sua localização em áreas montanhosas.

É de referir que a localização de instalações eólicas em terrenos baldios começou a partir de 2005 , sendo de $18 \%$ a percentagem geral dos PUB que referem essa presença (Figura 16). O maior número verifica-se nos baldios administrados por $\mathrm{CD}-\mathrm{CG}$, com um número médio de 0,7 eólicas/baldio. A invasão das torres de telecomunicações e parques eólicos em terrenos baldios ocorreu sem debate público (AFN, 2010). Na atualidade, dificilmente os baldios têm possibilidade de decidir ou participar neste tipo de negócios e isso deve ser corrigido através de políticas públicas (COPENA, 2018).

\section{Infraestruturas}

O perfil dos investimentos florestais, analisados mostrou que a maior atenção dos administradores dos baldios é dedicada ao desenvolvimento e manutenção de infraestruturas para a proteção da floresta existente (por exemplo, na construção e manutenção de redes viárias, na abertura e limpeza de pontos de água, entre outros) e não na renovação deste recurso depois da sua exploração. O mesmo facto foi também observado no estudo de BAPTISTA et al. (2002). 


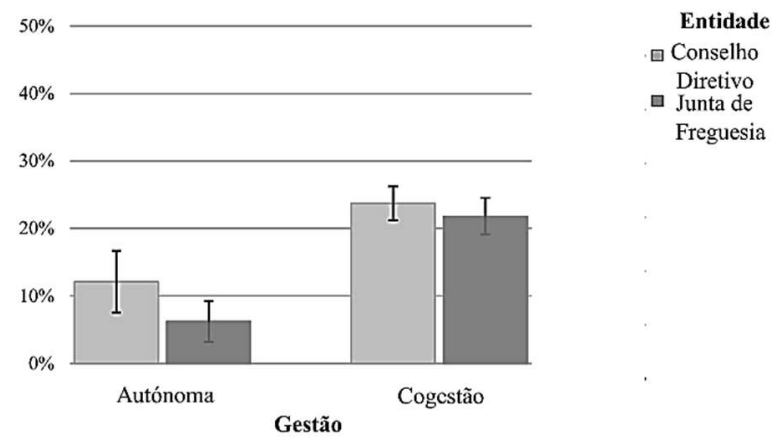

Figura 16 - Percentagem dos baldios com parques de eólicas por modalidade

\section{$\underline{\text { Rede viária }}$}

A atual rede viária surgiu no processo de implementação do plano de povoamento florestal e também de numerosos projetos subsequentes. O objetivo do seu desenvolvimento foi criar acesso ao interior dos povoamentos para facilitar a sua arborização e as operaç̃oes de condução cultural. Durante décadas, os Serviços Florestais asseguraram a manutenção e conservação dessas redes viárias (AFN, 2010). Hoje, após o retorno dos terrenos baldios e a redução gradual dos equipamentos e técnicos florestais, a maior parte deste trabalho é assegurada pelas entidades administradoras dos baldios.

Dos baldios analisados neste estudo, $95 \%$ possuem rede viária e em $70 \%$ as infraestruturas desta estão regularmente distribuídas. Metade dos terrenos baldios mantém mais de $50 \%$ das suas redes em boas ou aceitáveis condições. A análise estatística demonstrou que a distribuição da rede viária nestes baldios depende fortemente do tipo de gestão e não da entidade administradora (Quadro 3). Como seria de esperar, a maior quantidade de baldios com rede viária corresponde a baldios geridos por JF.

\section{$\underline{\text { Pontos de água }}$}

A água que alimenta fontes, chafarizes e levadas vem muitas vezes dos espaços comunitários (BAPTISTA, 2010). Nos próprios baldios, os pontos de água 
são associados a ribeiras, lagoas, açudes, barragens, tanques para rega, etc. Nas últimas décadas, o número e a diversidade do seu uso aumentou devido à necessidade de abastecer os equipamentos de combate aos incêndios florestais. Tratam-se de pontos de água para o abastecimento aéreo e terrestre, cujo número normalmente é definido no correspondente Plano Municipal de Defesa da Floresta Contra Incêndios das Câmaras Municipais, preparado pelo Gabinete Técnico Florestal.

Em média, cada baldio possui aproximadamente um ou mais pontos de água (a quantidade depende do tipo de gestão), e a sua manutenção é geralmente realizada em metade dos terrenos analisados, maioritariamente em baldios administrados por CD.

\section{Casas da guarda-florestal}

À escala nacional, existem mais de mil casas da guarda-florestal, com localizações privilegiadas em termos de proximidade à floresta e a paisagens montanhosas. Estes imóveis foram construídos entre 1888 e 1973, e estão principalmente nas áreas submetidas ao Regime Florestal, destinando-se originalmente à habitação dos guardas florestais (AFN, 2010).

Dos baldios analisados, $30 \%$ contêm casas de guarda (Figura 17) e muitas destas encontram-se hoje em dia em avançado estado de degradação. A venda de casas florestais pode originar incongruências jurídicas no âmbito da titularidade dos respetivos terrenos, visto que os imóveis pertencem ao domínio privado do Estado, mas a sua localização incide principalmente em áreas baldias.

Por outro lado, a sua localização em zonas com alto risco de incêndio florestal dificulta a sua transição para propriedade individual privada. Mas podem ser usadas na direção turística, onde a presença de valores naturais e culturais é um atributo integrante do turismo natural. Desse ponto de vista, o complexo de edifícios é muito atraente devido ao alto potencial paisagístico, relacionado com a sua localização. No entanto, devem ser procurados usos alternativos. 


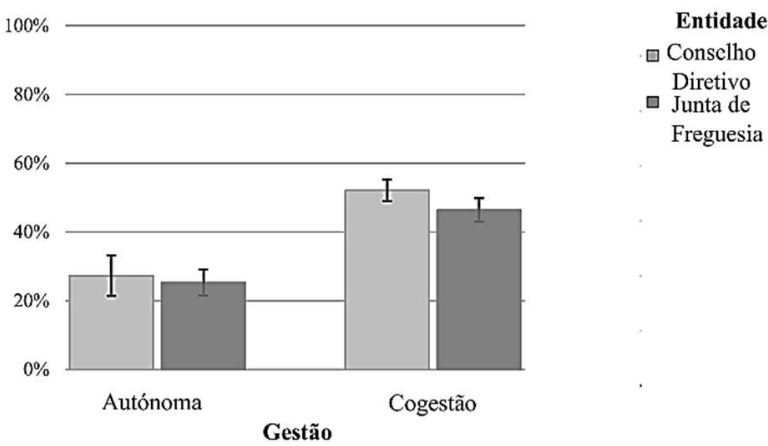

Figura 17 - Distribuição de casas de guarda-florestal, localizadas em terrenos baldios

Aptidões e estratégias de gestão

Após uma análise dos textos com descrição de "Aptidão Geral" verifica-se que, independentemente do tipo de modalidade a "Produção" é a aptidão mais mencionada no texto (Figura 18) e em aproximadamente $40 \%$ dos PUB analisados esta é mencionada como primeira e principal aptidão do baldio.

CD - CG

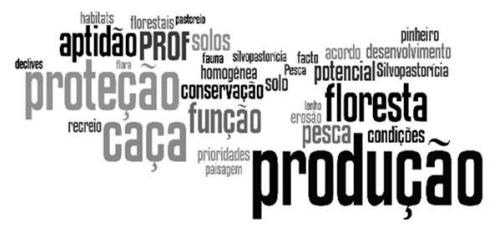

JF - CG

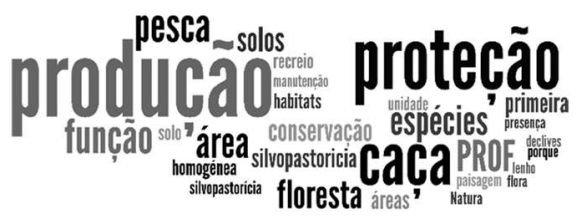

CD - GA

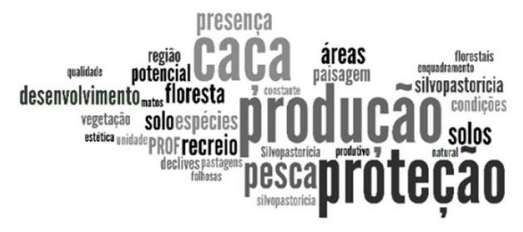

JF - GA

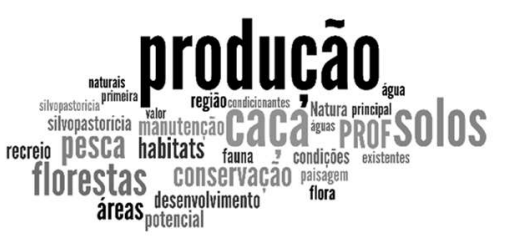

Figura 18 - Representação da importância relativa da menção às diversas aptidões gerais por modalidade 
O segundo "termo" mais mencionado na mesma descrição é a "Proteção". Refira-se que somente na modalidade JF-GA esse conceito não foi tomado em consideração. Ao contrário da tendência Europeia, verifica-se que em Portugal nos baldios a transição do seu uso de produção para proteção e conservação ainda está na sua fase inicial, embora segundo LOPES et al. (2015) mais de metade destas áreas esteja classificadas como áreas protegidas.

Em relação aos Produtos Florestais Não Lenhosos (PFNL), nomeadamente caça e pesca, mostram uma posição idêntica em todos os quadrantes da Figura 18.

Quanto à análise de textos descritivos de "Estratégias", os primeiros dois termos mais referidos são: "Floresta" e "Gestão" (Figura 19). Este facto parece demonstrar que os gestores de baldios interiorizaram que são os produtos florestais que maior renda produzem e, por tal, desejam continuar com a atividade florestal, mas com uma gestão adequada. Este resultado também coincide com as entrevistas, realizadas em colaboração com FAO, no âmbito de avaliação de 40 anos da Gestão Comunitária de Áreas Florestais (SKULSKA et al., 2017).

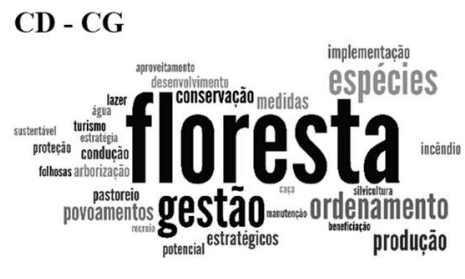

JF - CG

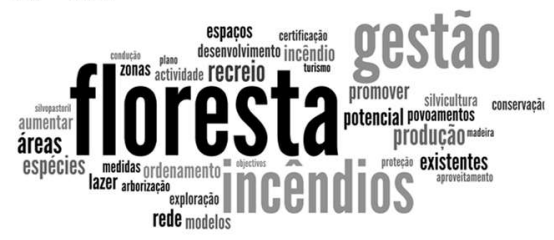

CD - GA

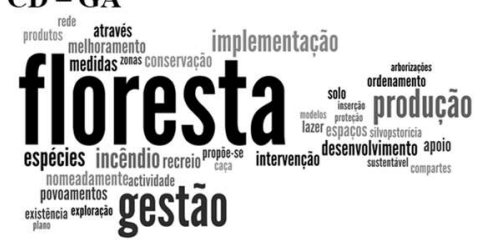

FF - GA

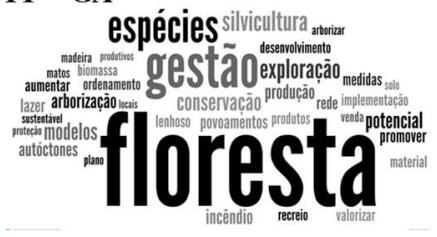

Figura 19 - Estratégias por modalidade

O termo "incêndios" inesperadamente só aparece com relevância na modalidade JF-CG. Esta questão deve ser alvo de estudo, ao nível do risco de incêndio em áreas baldias e de sensibilização dos diferentes atores que os gerem e usam. Tendo os conceitos "Proteção" e "Conservação" aparecido com pouca 
frequência nas descrições de estratégias destas áreas, tão importantes ao nível ambiental, impõe-se um aumento do seu peso (AFN, 2010; LOPES et al., 2015).

\section{Conclusões}

Este estudo confirma que o baldio é um tipo de propriedade muito importante no Norte e no Centro de Portugal, com áreas médias relativamente grandes, alto potencial de desenvolvimento e elevado uso agroflorestal. As áreas florestais baldias representam uma valiosa herança e um importante espaço para atividades florestais. Um pré-requisito para o seu usufruto sustentável, económico e ambiental, é o planeamento da sua gestão. Em 2006, arrancou o processo de elaboração dos Planos de Utilização dos Baldios, com o intuito de definir uma estratégia para o seu uso. Até 2019 foram desenvolvidos, aprovados e homologados 664 PUB que foram recolhidos, registados em base de dados e analisados. Este processo teve como objetivo a avaliação do quadro do seu atual estado e a sugestão de melhorias envolvendo a gestão dos recursos baldios e levando em consideração a transição dos valores económicos para inclusão dos valores sociais e ambientais.

Em termos gerais, pode dizer-se, com base nos resultados da análise, que existem diferenças significativas em diversas variáveis analisadas entre as modalidades, mas estas não são sempre no mesmo sentido, o que não permite concluir inequivocamente que no conjunto alguma modalidade seja sempre mais favorável do que as restantes. Parece que, no caso da governança dos terrenos comunitários, e sobretudo nas áreas florestais, a valorização social dos recursos, bem como a sua quantidade e qualidade, são mais determinantes da eficácia do sistema do que o tipo de modalidade da gestão (ou seja, o tipo dos atores envolvidos). O estudo mostrou também que a maioria dos baldios pretende dar continuidade à gestão florestal clássica, embora exista uma procura crescente por novas atividades. Mas, para aumentar a sustentabilidade da governança nos terrenos comunitários, são mesmo necessárias algumas alterações. Seguindo a estrutura deste estudo, todas as sugestões de melhoria, baseadas nos resultados obtidos, são também agrupadas em quatro vertentes principais, que são descritas de seguida: 


\section{Administração dos baldios}

A participação dos compartes (possuidores de terrenos baldios) na gestão dos seus recursos continua a ser insuficiente e exige a procura de soluções para a sua melhoria. O maior número de compartes interessados na gestão dos seus terrenos e recursos foi observada nos modelos de gestão CD-CG, que também apresentam maior área média e maior quantidade de área baldia incluída no Regime Florestal, o que indica a persistência de um problema de interpretação quanto ao conceito de "Comparte" e uma fraca sensibilização dos próprios compartes, e de outros agentes relevantes, no que diz respeito aos seus direitos e responsabilidades quanto às áreas baldias.

Assim, uma especial atenção deve ser dada aos trabalhos com os compartes das diferentes modalidades, bem como ao estudo das barreiras que impedem o interesse destes pela gestão do seu baldio. É igualmente importante desenvolver formas de integrar jovens na gestão do seu baldio, bem como estudar a importância que eles associam aos terrenos baldios para o seu futuro.

O investimento em áreas florestais continua a ser insuficiente. A promoção do investimento produtivo no baldio deve continuar a ser um dos pontos estratégicos para o desenvolvimento destes terrenos nos próximos anos e o seu cumprimento deve ser controlado pelo Estado.

\section{Recursos e atividades florestais}

As atividades silvícolas desempenham um importante papel na economia dos baldios e, como seria de esperar, a maior parte das áreas baldias dedica-se ao seu desenvolvimento e suporte. Reportando-nos ao ponto Composição da floresta, onde se apurou que a maioria dos povoamentos florestais baldios, é representada por resinosas, sem preocupações relativas ao tipo de gestão. Releva-se que esta realidade deve ser alterada sempre que se produzirem projetos de gestão florestal.

A alteração por introdução de espécies folhosas começou logo após a devolução dos baldios e surgiu devido à vontade de adaptar o uso de solo às necessidades locais. No entanto, a maior instalação de folhosas foi conseguida em modalidades sob gestão autónoma, uma vez que estas são mais independentes do Regime Florestal e o seu modelo de gestão é menos burocrático. Comparada com as monoculturas, a floresta mista tem um efeito muito mais benéfico em muitos serviços, incluindo a melhoria do crescimento 
das árvores. A maioria dos gestores de baldios deveria, num futuro próximo, reconsiderar a estratégia de gestão dos seus povoamentos a favor de uma reconversão para florestas mistas, aplicando as técnicas da silvicultura próxima de natureza, descritas por MONTEIRO (2013). Independentemente destas asserções, sugere-se a utilização no litoral norte da espécie Quercur robur, que apesar do seu limitado contributo atual é, fundamental ser valorizada à escala nacional, uma vez que é das espécies que mais se importa, o carvalho francês.

Quanto aos PUB, como o guia de gestão dos recursos e das áreas comunitárias, estes devem ser periodicamente atualizados, tendo em conta as alterações no terreno e outras oportunidades de melhoria.

De todas as atividades florestais analisadas, a fraca regeneração e arborização de parcelas pós-exploração merece especial atenção. A sua atual estagnação é causada pela influência de vários fatores: ambientais (frequentes incêndios e agravamento das condições fitossanitárias), decisões técnicas (realização de cortes frequentes e extração das melhores árvores) e administrativos (preocupação dos administradores dos baldios quanto à perda de investimento na reflorestação, devido aos vários e elevados riscos). Além disso, pouca atenção parece ser dada à diminuição do risco de incêndio e à luta contra espécies invasoras, apesar de os gestores dos baldios reconhecerem estas ameaças. O problema permanece por resolver e o seu estado atual é agravado pelas alterações climáticas. Por conseguinte, a questão da reflorestação dos povoamentos baldios requer mais pesquisas e uma busca por novas maneiras de aumentar a resiliência.

Quanto às equipas de sapadores, presentes em apenas um quinto dos baldios, o seu número, bem como o leque de serviços por elas prestados, deve ser aumentado num próximo futuro e as condições de contratação melhoradas.

\section{Outros recursos dos baldios}

O aproveitamento de produtos florestais não lenhosos é sempre vantajoso e lucrativo para a economia dos baldios, pois as receitas provenientes deste tipo de produtos não estão sujeitas a repartição com o Estado, como no caso da madeira explorada dentro do Regime Florestal. A exploração da maioria desses recursos está mais relacionada com a sua localização geográfica e/ou acesso livre às áreas baldias do que com o tipo de gestão ou entidade gestora. E enquanto alguns recursos estão melhor explorados (p.e. pastagem, caça) outros permanecem subestimados apesar do seu potencial económico (como p.e. cogumelos, 
apicultura, arrendamentos, serviços ambientais produzidos pelas áreas florestais baldias, etc.).

\section{Aptidões e estratégias de gestão}

Realça-se que em todas as modalidades avaliadas a "Produção" foi aquela a que sempre foi dada maior atenção e dimensão. Também na estratégia dos PUB analisados se verifica que esta opção ocupa o primeiro lugar.

Das outras atividades examinadas aparece com peso significativo a aptidão de "Proteção". Presentemente, é reconhecido o valor de serviços do ecossistema produzidos por terrenos baldios, porém, este não tem tido tradução económica. É inevitável que todas as atividades relacionadas com proteção e conservação em áreas baldias sejam devidamente apoiadas.

Passando à estratégia dos PUB parece não ser dada suficiente atenção ao risco de incêndio e ao controlo de invasoras na gestão, tendo em conta o alto valor ecológico dos baldios. As previstas alterações climáticas exigem que estas vertentes sejam cada vez consideradas minimizando as consequentes perdas.

A ferramenta dos Planos de Utilização dos Baldios, se incluída num processo continuado, permite a monitorização dos recursos e da sua gestão, bem como o seu grau de enquadramento em planos de ordenamento da floresta e do território em diferentes escalas. Assim, a atualização periódica dos PUB bem como o acompanhamento da sua execução deverão ser componentes essenciais de um processo de melhoria contínua da gestão dos terrenos comunitários.

\section{Agradecimentos}

Este estudo foi apoiado financeiramente pela FCT (Fundação para Ciência e Tecnologia). Bolsa de Doutoramento PD / BD / 113939/2015. Agradece-se ao ICNF e BALADI o acesso aos dados de base dos PUB. Um agradecimento especial ao Armando Carvalho, Pedro Gomes e Paulo Gomes, pelo encorajamento e as importantes discussões ao longo deste trabalho.

\section{Bibliografia}

AFN, 2010. Relatório da Comissão Nacional para a Valorização dos Territórios Comunitários. MADRP. AFN. Lisboa. Trabalho não publicado, $82 \mathrm{pp}$. 
BAPTISTA, F., 2010. O espaço rural: declínio da agricultura. $1^{\text {a }}$ edição. Lisboa, 213 pp.

BAPTISTA, F., LOURENÇO, F., TERRA SANTOS, R., 2002. Propriedade e gestão dos baldios e suas implicações para o desenvolvimento rural das zonas periféricas. Relatório final do projeto FAIR6-CT98-4111. Lisboa, 41 pp.

CANADAS, M., NOVAIS, A., 2014. Proprietários florestais, gestão e territórios rurais. Análise Social, 211. (also available at http://www.scielo.mec.pt/ scielo.php? pid=S000325732014000200005\&script=sci_arttext\&tlng=en).

COPENA, D., 2018. Atividades promovidas ou interferindo com os baldios mediante contrato de cadência: os parques eólicos. Associativismo em áreas comunitárias. BALADI-Federação Nacional de Baldios, pp. 61-79, Vila Real.

DEVY-VARETA, N., 2003. O Regime Florestal em Portugal através do século XX (1903 2003). Revista da Faculdade de Letras - Geografia XIX (1): 447-455.

FERREIRA, J., SOARES, C., 2013. O conhecimento das instituições comunitárias: regime jurídico. In C.U. de Coimbra, ed. SCRAM - Crises, gestão de risco e novos arranjos sócio ecológicos para florestas. Uma perspetiva dos estudos sobre ciência e tecnologia. Relatório do projeto PTDC/CS-ECS/099630/2008, pp. 242-282.

GERMANO, A., 2000. Regime Florestal. Um século de existência. Lisboa, Direção Geral Recursos Florestais 159 pp.

GERMANO, A., 2013. Áreas Públicas e Comunitárias. Uma Floresta Diferente. In J. Bento, J. Lousada \& M. Sameiro Patrício, eds. $7^{\text {a }}$ Congresso Florestal Nacional "Florestas Conhecimento e Inovação". Sociedade Portuguesa de Ciências Florestais, pp. 184-199, Vila Real e Bragança.

GOMES, P., 2009. Posse, gestão e uso de recursos em regime de propriedade comum - Os Baldios do Norte de Portugal. Dissertation, University of Lisbon. (also available at http://hdl.handle.net/10400.5/2521).

LOPES, L., BENTO, J., CRISTOVÃO, A., BAPTISTA, F., 2015. Exploring the effect of land use on ecosystem services: The distributive issues. Land Use Policy 45: 141-149. https://doi.org/10.1016/j.landusepol.2014.12.008

LUZ, A.L., 2017. Drama institucional e relações de poder nos baldios do Parque Nacional da Peneda-Gerês. Finisterra 52(105): 7-27. https://doi.org/10.18055/Finis9824

MA, (Ministério da Agricultura), 1939. Reconhecimento dos baldios do continente. Junta de Colonização Interna Vol. I e II. Lisboa, 3022 pp.

MONTEIRO, M.L., 2000. Trás-os-Montes um lugar de Castanheiros. In R. Pereira, ed. Florestas de Portugal. Lisboa, Direção Geral das Florestas.

MONTEIRO, M.L., 2013. Silvicultura Próxima da Natureza. In F.C. REGO, J. BENTO, J. AZEVEDO, M.L. MONTEIRO, E. SOUSA \& G. LOURO, eds. A Floresta Portuguesa. Academia das Ciências de Lisboa pp. 33-37, Lisboa.

PINHO, J., SANTOS, C., LEITE, A., GERMANO, A., 2012. Estratégia para a gestão das matas nacionais. Relatório. Versão preliminar. ICNF, Lisboa.

RADICH, M., BAPTISTA, F., 2005. Floresta e sociedade: um percurso (1875-2005). Silva Lusitana 13(2): 143-157.

REGO, F., 2001. Florestas Públicas. MADRP. DGF. CNEFF, 105 pp. 
130 Skulska, I., Monteiro, M.L. e Rego, F.C.

REGO, F., SKULSKA, I., 2019. Avaliação histórica do Regime Florestal em Portugal. In M. Antunes e D. Lopes, eds. Florestas e legislação: que futuro? Instituto Jurídico da Faculdade de Direito da Universidade de Coimbra, pp. 75-85.

SERRA, R., RODRIGUES, E., GARCÍA-BARRIOS, R., 2017. Mushrooming Communities: A Field Guide to Mycology in the Community Forests of Portugal. Sustainability 9(6): 924. https://doi.org/10.3390/su9060924

SERRA, R., ALLEGRETTI, G., ROMÁN, A., ANSALONI, C., 2018. Escolas comunitárias COMUNIX. Centro de Estudos Sociais da Universidade de Coimbra, 38 pp. (also available at https://estudogeral.sib.uc.pt/bitstream/10316/85301/1/Escolas Comunitárias COMUNIX.pdf).

SKULSKA, I., COLAÇO, M.C., MONTEIRO, M., REGO, F.C., 2017. Report of CEABN. Assessment of Community Based Forestry with FAO methodology. Instituto Superior de Agronomia. Unpublished work, $67 \mathrm{pp}$.

SKULSKA, I., COLAÇO, M.C., AGGARWAL, S., DIDIER, H., MONTEIRO, M., REGO, F.C., 2020. Assessment of Portuguese Community Forestry using the Voluntary Guidelines on the Responsible Governance of Tenure and FAO Community-Based Forestry Framework. Society \& Natural Resources 33(1): 101-121. https://doi.org/10.1080/ $\underline{08941920.2019 .1660934}$

This is an Open Access article distributed under the terms of the Creative Commons Attribution License (https://creativecommons.org/licenses/by/4.0), which permits unrestricted use, distribution, and reproduction in any medium, provided the original work is properly cited. 